\title{
Acanthoic Acid and other Constituents from the Stem of Annona amazonica (Annonaceae)
}

\author{
Maria Lúcia B. Pinheiro, ${ }^{*, a}$ Clahildek M. Xavier, ${ }^{a}$ Afonso D. L. de Souza, ${ }^{a}$ Diego de Moura Rabelo, ${ }^{a}$ \\ Cristiane L. Batista, ${ }^{b}$ Regiane L. Batista, ${ }^{b}$ Emmanoel V. Costa, ${ }^{b}$ Francinete R. Campos, ${ }^{b}$ \\ Andersson Barison, ${ }^{b}$ Rodrigo H. Valdez, ${ }^{c}$ Tânia Ueda-Nakamura ${ }^{c}$ and Celso V. Nakamura ${ }^{c}$ \\ ${ }^{a}$ Departamento de Química, Universidade Federal do Amazonas, 69077-000 Amazonas-AM, Brazil \\ ${ }^{b}$ Departamento de Química, Centro Politécnico, Universidade Federal do Paraná, 81530-900 Curitiba-PR, Brazil \\ 'Departamento de Análises Clinicas, Universidade Estadual de Maringá, 87020-900 Maringá-PR, Brazil
}

\begin{abstract}
O presente trabalho descreve o isolamento, a partir do caule de Annona amazonica, do ácido acantóico, um diterpeno do tipo pimaradieno que possui várias e importantes atividades biológicas descritas na literatura. Neste estudo foi verificado que este composto apresenta significante atividade tripanocida contra as formas epimastigotas de Trypanosoma cruzi. Também foi constatado que este diterpeno é o constituinte majoritário da planta, encontrado em cerca de $65 \%$ do extrato hexânico, demonstrando que A. amazonica é uma nova fonte natural renovável desta substância. Além do ácido acantóico, a investigação química resultou no isolamento dos alcalóides liriodenina e cassiticina, entre outros compostos, tais como terpenos, esteróides e ácidos graxos. Adicionalmente, é descrita a completa e inequívoca atribuição dos deslocamentos químicos de $\mathrm{RMN}$ de ${ }^{1} \mathrm{H} \mathrm{e}{ }^{13} \mathrm{C}$ da cassiticina.
\end{abstract}

The present work reports the isolation of acanthoic acid, a promising pimaradiene-type diterpene with several important biological activities described in the literature, from the stems of Annona amazonica. We found that acanthoic acid has significant trypanocidal activity against the epimastigote forms of Trypanosoma cruzi. This diterpene is the major constituent of the plant, comprising at least $65 \%$ of the hexane extract, demonstrating that $A$. amazonica is a new renewable natural source for this compound. The chemical investigation also resulted in the isolation of the alkaloids liriodenine and cassythicine, and other compounds including terpenes, sterols, and fatty acids. Additionally, the complete and unequivocal ${ }^{1} \mathrm{H}$ and ${ }^{13} \mathrm{C}$ NMR chemical shift assignments for cassythicine are provided.

Keywords: Annona amazonica, Annonaceae, acanthoic acid, cassythicine, trypanocidal activity

\section{Introduction}

The family Annonaceae, comprised of tropical and subtropical species with about 135 genera and more than 2500 species and widely distributed in South and Central America, Africa, Asia, and Australia, ${ }^{1}$ is known for its edible fruits and the medicinal properties of several species. ${ }^{2}$ In Brazil, there are 26 genera with about 260 species, including the genus Annona, which contains approximately 120 species. $^{3}$

Chemical investigations of species of Annonaceae have revealed their high chemical diversity in terms of secondary metabolites, such as alkaloids, acetogenins,

*e-mail: lbelem@ufam.edu.br terpenoids and lactones. These compounds have shown important biological activities, including antiparasitic, in particular against Leishmania sp., Plasmodium falciparum, and Trypanosoma cruzi. ${ }^{4-12}$

Annona amazonica R.E. Fries is a tropical tree that grows up to $20-25 \mathrm{~m}$ tall and $35-60 \mathrm{~cm}$ in diameter, and is found from Panama to South America. In Brazil this species commonly occurs in the Amazon, mainly in the states of Amazonas and Pará. ${ }^{13}$ To the best of our knowledge, only one previous phytochemical study has described the isolation and identification of cyanogenic constituents from this species. ${ }^{14}$

Here we describe the isolation and structural identification of the chemical constituents from the stems of A. amazonica, including acanthoic acid (1), a 
promising compound with several important biological activities described in the literature. This compound was found to be the principal component of A. amazonica, and showed trypanocidal activity against epimastigote forms of Trypanosoma cruzi, the causative agent of Chagas' disease. In addition, the full NMR analyses of the alkaloid cassythicine (3) are included.

\section{Experimental}

\section{General procedures}

1D and 2D NMR experiments were recorded on a Bruker AVANCE 400 spectrometer operating at $9.4 \mathrm{~T}$, equipped with a $5 \mathrm{~mm}$ multinuclear direct detection probe with $z$-gradient, observing ${ }^{1} \mathrm{H}$ and ${ }^{13} \mathrm{C}$ at 400.13 and $100.61 \mathrm{MHz}$, respectively. ${ }^{1} \mathrm{H}-{ }^{13} \mathrm{C}$ correlation (HSQC and HMBC) experiments were performed with the average coupling constant ${ }^{1} J(\mathrm{C}, \mathrm{H})$ and ${ }^{\mathrm{LR}} J(\mathrm{C}, \mathrm{H})$ optimized for 140 and $8 \mathrm{~Hz}$, respectively. The $1 \mathrm{D}$ nOe experiments were obtained by selective excitation of each ${ }^{1} \mathrm{H}$ NMR frequency and gradient selection using the double-pulsed field gradient spin-echo (DPFGSE)-nOe experiment with constant mixing time of $500 \mathrm{~ms}$. IR spectra were recorded in $\mathrm{KBr}$ pellets on a Perkin-Elmer Spectrum 2000 spectrometer. Low resolution ESIMS and ESI-MS/MS data were taken in positive ion mode, on a Micromass Quatro LC mass spectrometer, equipped with an ESI/APCI "Z-spray" ion source. GC-MS analyses were performed on an Agilent Technologies $6896 \mathrm{~N}$ instrument equipped with a HP-5MS $(29.6 \mathrm{~m} \times 0.25 \mathrm{~mm} ; 0.25 \mu \mathrm{m}$ film thickness) fusedsilica capillary-column. The following conditions were used: temperature program: $70{ }^{\circ} \mathrm{C}$ for $5 \mathrm{~min} ; 5^{\circ} \mathrm{C} \mathrm{min}^{-1}$ until $300{ }^{\circ} \mathrm{C}$; $300{ }^{\circ} \mathrm{C}$ for $20 \mathrm{~min}$; injector temperature: $250{ }^{\circ} \mathrm{C}$; carrier gas: helium, adjusted to a linear rate of $32 \mathrm{~cm} \mathrm{~s}^{-1}$ (measured at $100{ }^{\circ} \mathrm{C}$ ); injection type: split flow, adjusted to give a 1:20 ratio; septum sweep constant at

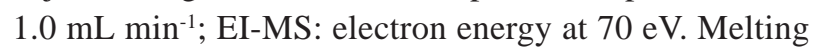
points were obtained on a Quimis Q-340S23 micromelting apparatus. Optical rotations were measured on a Rudolph Research Autopol III polarimeter. Gravity-column chromatography (CC) was carried out on silica gel 60 (70-230 mesh, Merck), while analytical and preparative thin-layer chromatography (TLC) was run on $0.25 \mathrm{~mm}$ thick aluminum-backed silica-gel 60 plates type $\mathrm{F} / \mathrm{UV}_{254}$ and 366 (Merck) and $2 \mathrm{~mm}$ thick glass-backed silica gel 60 plates type $\mathrm{P} / \mathrm{UV}_{254}$ (Macherey-Nagel), respectively. The spots were detected by exposure to UV light at 254 or $366 \mathrm{~nm}$, as well as by spraying with Dragendorff's reagent or 5\% $\mathrm{H}_{2} \mathrm{SO}_{4}$ in EtOH and then heating on a hot plate.

\section{Botanical material}

The stems of A. amazonica weres collected in May 2003 in the Adolpho Ducke Forest Reserve (coordinates: $02^{\circ} 54^{\prime} 26^{\prime \prime}$ to $03^{\circ} 00^{\prime} 22^{\prime \prime} \mathrm{S}$; $59^{\circ} 52^{\prime} 40^{\prime \prime}$ to $59^{\circ} 58^{\prime} 40^{\prime \prime} \mathrm{W}$ ), situated $26 \mathrm{~km}$ northeast of the city of Manaus in the state of Amazonas, and identified by a specialist in Annonaceae, Prof. Dr. A.C. Webber. A voucher specimen (\# 1796) was deposited in the Herbarium of the Instituto Nacional de Pesquisas da Amazônia (INPA).

\section{Extraction and isolation}

The powdered air-dried stems of A. amazonica $(1.7 \mathrm{~kg})$ were extracted successively with $n$-hexane $(4 \times 2 \mathrm{~L}), \mathrm{CH}_{2} \mathrm{Cl}_{2}(4 \times 2 \mathrm{~L})$, and $\mathrm{MeOH}(4 \times 2 \mathrm{~L})$, at room temperature. Removal of the solvents under reduced pressure gave hexane (10.5 g), $\mathrm{CH}_{2} \mathrm{Cl}_{2}(6.0 \mathrm{~g})$, and $\mathrm{MeOH}$ $(30.0 \mathrm{~g})$ extracts.

\section{Hexane extract: isolation of 1 and GC-MS analysis}

The hexane extract yielded large crystals in very high quantity. These were manually collected, washed in hexane, and submitted directly to NMR and other spectroscopic investigations. They were identified as a pimaradiene-type diterpene, (-)-ent-pimara-9(11),15-dien-19-oic acid or acanthoic acid (1, 6.9 g). After the acanthoic acid crystals were removed, $10 \mathrm{mg}$ of the remaining hexane extract was methylated with diazomethane and submitted to GCMS analyses according to the conditions described in the general procedures, above. The chemical constituents were identified on the basis of their $\mathrm{GC}$ retention indices with reference to a homologous series of $\mathrm{C}_{8}-\mathrm{C}_{26} n$-alkanes, as well as by matching their mass spectra with those from the NIST 98 MS and Wiley 7n MS libraries, and by comparing the fragmentation patterns of the mass spectra with those reported in the literature. ${ }^{15}$

\section{Dichloromethane extract: isolation of 1-10}

TLC investigations indicated the presence of alkaloids in the $\mathrm{CH}_{2} \mathrm{Cl}_{2}$ extract by exposure to Dragendorff's reagent. Therefore, this extract was redissolved in $\mathrm{CH}_{2} \mathrm{Cl}_{2}(100 \mathrm{~mL})$ and subjected to an acid-base extraction with $3 \%$ aqueous $\mathrm{HCl}(6 \times 200 \mathrm{~mL})$, resulting in organic $\mathrm{CH}_{2} \mathrm{Cl}_{2}$ and aqueous fractions. The organic $\mathrm{CH}_{2} \mathrm{Cl}_{2}$ fraction was submitted to solvent removal under reduced pressure to yield a neutral fraction $(4.9 \mathrm{~g})$. The aqueous fraction was adjusted to $\mathrm{pH}$ 12 with $\mathrm{NH}_{4} \mathrm{OH}$ and submitted to a new extraction with $\mathrm{CH}_{2} \mathrm{Cl}_{2}(7 \times 200 \mathrm{~mL})$. Following this, the $\mathrm{CH}_{2} \mathrm{Cl}_{2}$ parts were combined and the solvent evaporated under reduced pressure to yield the alkaloid fraction $(0.8 \mathrm{~g}) .{ }^{9}$ 


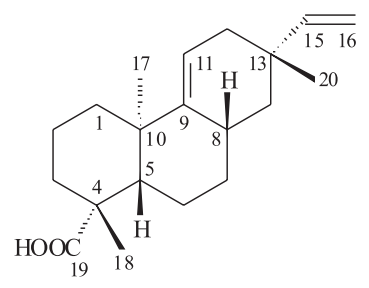

1
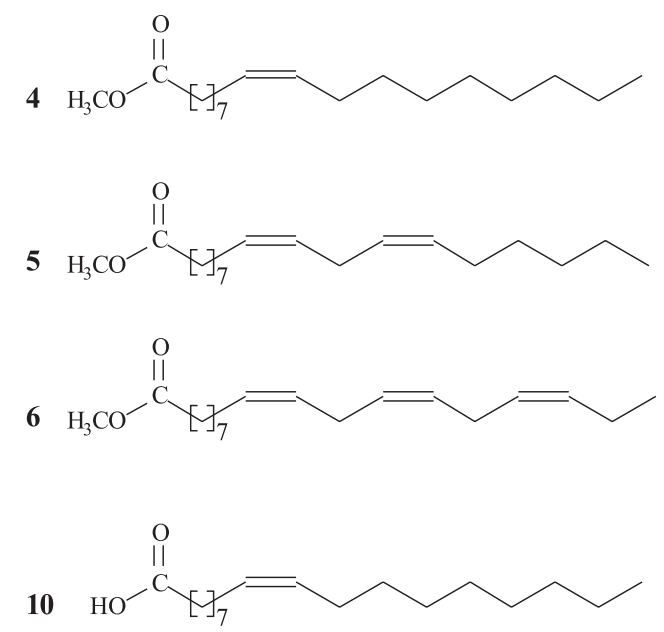

The alkaloid fraction $(0.7 \mathrm{~g})$ was initially subjected to silica-gel column chromatography (CC), previously treated with a $10 \% \mathrm{NaHCO}_{3}$ solution ${ }^{9}$ and eluted with increasing concentrations of $\mathrm{CH}_{2} \mathrm{Cl}_{2}$ in hexane, followed by EtOAc in $\mathrm{CH}_{2} \mathrm{Cl}_{2}$, and $\mathrm{MeOH}$ in EtOAc. The eluted fractions $(30 \mathrm{~mL})$ were evaluated and pooled by TLC analysis, affording 10 subfractions. Subfraction 5 (200 $\mathrm{mg}$ ) was further purified by silica gel CC using the same methodology as above, and subsequently on preparative TLC eluted with $\mathrm{CH}_{2} \mathrm{Cl}_{2}-\mathrm{MeOH}$ (95:05, v/v), resulting in the oxoaporphine alkaloid liriodenine $(\mathbf{2}, 4 \mathrm{mg})$, and in the aporphine alkaloid cassythicine $(\mathbf{3}, 6 \mathrm{mg})$.

The neutral fraction (4.5 g) was initially subjected to silica-gel CC, and eluted with increasing concentrations of $\mathrm{CH}_{2} \mathrm{Cl}_{2}$ in hexane, followed by EtOAc in $\mathrm{CH}_{2} \mathrm{Cl}_{2}$ and $\mathrm{MeOH}$ in EtOAc. The eluted fractions $(10 \mathrm{~mL})$ were evaluated and pooled by TLC analysis, giving 18 groups (A-M). Group F (700 mg) was purified by silica-gel CC eluted with increasing concentrations of $\mathrm{CH}_{2} \mathrm{Cl}_{2}$ in hexane, to give five subfractions (If-Vf). Subfraction IIf yielded a mixture of three methyl esters of the fatty acids, oleic, linoleic, and linolenic (4, 5 and 6, $44 \mathrm{mg}$ ). Subfractions IIIf-Vf afforded acanthoic acid $(\mathbf{1}, 385 \mathrm{mg})$, and the sesquiterpene, caryophyllene oxide (7, $11 \mathrm{mg}$ ) after being purified by preparative TLC eluted with hexane-EtOAc (90:10, v/v). Group K (300 mg) was further purified by silica-gel CC eluted with the same gradient system described previously, to give seven subfractions

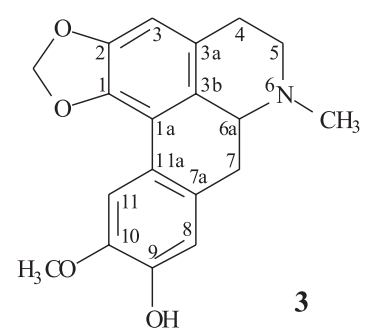<smiles>C=C1CCC23O[C@]2(C)CCC32C(C)CC1C2(C)C</smiles><smiles>CCC(CC[C@H](C)[C@H]1CC[C@H]2[C@H]3CC=C4CC(O)CCC4(C)[C@H]3CC[C@@]21C)C(C)C</smiles>

(Ik-VIIk). Subfraction IIIk was purified by preparative TLC eluted with hexane-EtOAc (80:20, v/v) to give a mixture of two steroids, $\beta$-sitosterol and stigmasterol (8 and 9, $66 \mathrm{mg}$ ). Subfraction IVk yielded a mixture containing acanthoic acid (1, $22 \mathrm{mg}$ ). Group N (558 mg) was further purified by using silica-gel CC eluted with the same gradient system described previously, to give eight subfractions. Subfractions Vn and VIIIn yielded one monounsaturated fatty acid, oleic acid (10,36 mg), and in a mixture of three methyl esters of the fatty acids, oleic, linoleic, and linolenic $(\mathbf{4}, \mathbf{5}$, and $6,36 \mathrm{mg}$ ), respectively. Additionally, all fractions that showed the presence of high amounts of acanthoic acid as evidenced by ${ }^{1} \mathrm{H}$ NMR analysis were pooled and purified according to the conditions described above, to give $1.8 \mathrm{~g}$ of this compound.

In vitro trypanocidal activity assay

\section{Parasite}

The epimastigote form of Trypanosoma cruzi strain Y was grown in liver infusion tryptose (LIT) supplemented with $10 \%$ fetal-calf serum (FCS, Gibco) at $28{ }^{\circ} \mathrm{C}$ for $96 \mathrm{~h}$.

\section{Cell culture}

LLCMK $_{2}$ (monkey kidney cells) were maintained in DMEM supplemented with $2 \mathrm{mmol} \mathrm{L}^{-1} \mathrm{~L}$-glutamine, $10 \%$ 
FCS, and $50 \mathrm{mg} \mathrm{L}^{-1}$ gentamycin, and buffered with sodium bicarbonate.

\section{Antiproliferative activity on epimastigote form}

The epimastigote form of T. cruzi in the logarithmic phase was used for this assay. Acanthoic acid was redissolved in DMSO and LIT medium to obtain concentrations of 3, 16, 33,165 , and $331 \mu \mathrm{mol} \mathrm{L}-1$ at the well. The final concentration of DMSO did not exceed $1 \%$. For each experiment, there was a growth control with and without DMSO.

Cells at a density of $1 \times 10^{6}$ epimastigotes $\mathrm{mL}^{-1}$ were cultured in a 24 -well microplate to obtain a final volume of $1 \mathrm{~mL}$. The cells were incubated at $28{ }^{\circ} \mathrm{C}$ and their growth was determined by counting the parasites with a hemocytometer chamber after $96 \mathrm{~h}$. The $\mathrm{IC}_{50}$ value $(50 \%$ inhibition concentration) was determined using linear regression analysis from the inhibition percentage. These tests were performed in triplicate on separate occasions. ${ }^{16}$

\section{Cytotoxicity assay}

The cellular toxicity was evaluated against the $\mathrm{LLCMK}_{2}$ cell line in 96-well plates. The cells were seeded onto microplates at a concentration of 2.5 cells $\times 10^{5}$ cells $\mathrm{mL}^{-1}$, and incubated in DMEM supplemented with $10 \%$ FCS. The monolayer obtained was treated with different concentrations of acanthoic acid $(20 ; 41 ; 82 ; 165 ; 331$; $1655 ; 3311 \mu \mathrm{mol} \mathrm{L}-1)$. DMSO was used as the negative control. After incubation at $37{ }^{\circ} \mathrm{C}$ with $5 \% \mathrm{CO}_{2}$ for $96 \mathrm{~h}$, cell viability was evaluated by the sulforhodamine $\mathrm{B}$ technique. ${ }^{17}$ The absorbance was read at $530 \mathrm{~nm}$ in a microplate spectrophotometer (Biotek-Power wave XS). The $\mathrm{CC}_{50}$ of the substance (the concentration that lysed $50 \%$ of the cells) was calculated. These tests were performed in duplicate on separate occasions.

\section{Results and Discussion}

\section{Chemical studies}

Members of the genus Annona have a good ability to produce alkaloids, a class of compounds typically found in species of the family Annonaceae. However, $A$. amazonica produces as its major secondary metabolite, the pimaradiene-type diterpene acanthoic acid (1), as evidenced by the surprising and extraordinary appearance of large glassy prism crystals in very high quantities, practically $65 \%$ of the hexane extract, which allowed their direct collection and investigation by spectrometric methods, mainly by NMR analysis, without the need of any additional purification procedure. Compound $\mathbf{1}$ showed an uncorrected melting point at $134-135{ }^{\circ} \mathrm{C},[\alpha]^{25}$ of $-50.4^{\circ}$ $\left(c=1.25, \mathrm{CHCl}_{3}\right)$, IR bands (KBr) at 3200-3081, 1692, 1636, and $908 \mathrm{~cm}^{-1}$ and EI-MS ion peaks at $\mathrm{m} / \mathrm{z}$ (rel.

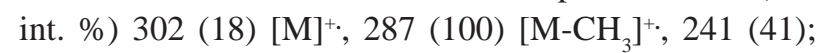
and 234 (26). The ${ }^{1} \mathrm{H}$ NMR spectra showed four olefinic signals whose coupling constants allowed the assignment of a monosubstituted terminal double bond, related to the signals at $\delta 4.93(d d, J 17.5,1.4 \mathrm{~Hz}), 4.86(d d, J 10.7$, $1.4 \mathrm{~Hz})$, and $5.81(d d, J 17.5,10.7 \mathrm{~Hz})$, and a trisubstituted double bond (signal at $\delta 5.40, d d, J 5.4,4.8 \mathrm{~Hz}$ ) that is characteristic for the ring $\mathrm{C}$ position $\Delta^{9(11)}$ of pimaradienetype diterpenes. ${ }^{18}$ These findings, confirmed by ${ }^{13} \mathrm{C}$ NMR data as well as by one-bond and long-range heteronuclear ${ }^{1} \mathrm{H}-{ }^{13} \mathrm{C}$ correlations from HSQC and HMBC experiments, along with the MS fragmentation pattern, mainly by the ion at $\mathrm{m} / \mathrm{z} 234$, attributed to an elimination of 2-methylbutadiene by a retro-Diels-Alder process, allowed us to establish the structure of $\mathbf{1}$ as acanthoic acid. ${ }^{18}$ Additionally, all relative configurations in $\mathbf{1}$ were established by 1D nOe experiments, as follows. Selective irradiation of the resonance frequency of $\mathrm{H}-20$ caused a nOe enhancement in the signal of $\mathrm{H}-8$, and selective irradiation of the resonance frequency of $\mathrm{H}-18$ showed a nOe intensification in the signal of $\mathrm{H}-5$, but not in the signal of $\mathrm{H}-17$. On the other hand, selective irradiation of the resonance frequency of $\mathrm{H}-17$ did not cause any nOe enhancement in the signals of $\mathrm{H}-5, \mathrm{H}-8$, and $\mathrm{H}-18$, indicating that $\mathrm{H}-5$ and $\mathrm{H}-8$ are located on the same side of the molecule as methyl groups C-18 and C-20. These results are in full accordance with those previously described for acanthoic acid..$^{18}$ Moreover, almost all of the investigated fractions of the $\mathrm{CH}_{2} \mathrm{Cl}_{2}$ extract contained high amounts of $\mathbf{1}$, as evidenced by ${ }^{1} \mathrm{H}$ NMR analysis. Acanthoic acid (1) was first isolated from Acanthopanax koreanum (Araliaceae) ${ }^{18}$ and has also been reported from Mikania sp. (Asteraceae), ${ }^{19}$ Rollinia pittieri and $R$. exsucca (Annonaceae). ${ }^{20}$ Therefore, this is the fifth description of $\mathbf{1}$ in the literature, the first in the genus Annona, and the third in the family Annonaceae, which is important from a chemotaxonomic point of view.

Several important in vitro and in vivo biological activities against a wide range of diseases and medical conditions, mainly antitumor and anti-inflammatory, have been described in the literature for $\mathbf{1} .^{21-33}$ These findings clearly show the medicinal potential of $\mathbf{1}$. However, almost all of the biological activities described in the literature for $\mathbf{1}$ have been shown by the compound extracted from Acanthopanax koreanum, which resulted in the protection of the process for its extraction from this plant by an international patent, ${ }^{21}$ and has attracted interest in its synthetic preparation and modification. ${ }^{26,29,34,35}$ Therefore, according to the results of the present study, a new renewable natural source for 
acanthoic acid (1) from Annona amazonica has been demonstrated, which can advance research for new drugs based on this compound.

After the acanthoic acid (1) crystals were removed from the hexane extract, GC-MS analyses also allowed us to identify several other constituents that were present in lower concentrations: sesquiterpenes, $\beta$-cubebene $(0.73 \%), \alpha$-cubebene $(0.90 \%), \alpha$-humulene $(1.24 \%)$, $\alpha$-amorphene (1.54\%), $\alpha$-copaene (2.08\%), caryophyllene oxide $(3.12 \%), \alpha$-muurolene $(4.56 \%)$, trans-caryophyllene $(4.70 \%), \delta$-cadinene $(7.22 \%), \gamma$-cadinene $(11.11 \%)$, and germacrene D (12.43\%); ${ }^{15}$ fatty acids: hexadecanoic acid, methyl ester, or methyl palmitate (1.09\%), (Z,Z)-9,12octadecadienoic acid, methyl ester, or methyl linoleate $(0.12 \%)$, and (Z)-9-octadecenoic acid, methyl ester, or methyl oleate $(0.28 \%){ }^{36}$

The chemical investigation of the alkaloid fraction of the $\mathrm{CH}_{2} \mathrm{Cl}_{2}$ extract resulted in the isolation and identification of the oxoaporphine alkaloid liriodenine (2) as yellow needles $\left(\mathrm{mp} 280-281{ }^{\circ} \mathrm{C}\right.$ ) and the aporphine alkaloid cassythicine or $\mathrm{N}$-methylactinodaphnine (3) as white needles (mp 204$205^{\circ} \mathrm{C}$ ). Liriodenine $(2)$ is frequently found in species of Annonaceae $e^{4,9,37-42}$ and therefore can be considered as a chemotaxonomic marker of this family, since it can be found in most of the genera. On the other hand, cassythicine (3) is more commonly found in species of Lauraceae, a family phylogenetically close to the Annonaceae, particularly in the genera Cassytha, Laurus, Litsea, Stephania, and Neolitsea; however, it is also found in some species of the genus Annona, such as A. glabra. ${ }^{37-40,43}$ Additionally, the neutral fraction of the $\mathrm{CH}_{2} \mathrm{Cl}_{2}$ extract yielded acanthoic acid (1) ${ }^{17}$ three methyl esters of fatty acids $\mathbf{4}, \mathbf{5}$, and $\mathbf{6},{ }^{4,36}$ one sesquiterpene $\mathbf{7},{ }^{44}$ a mixture of the steroids $\mathbf{8}$ and $\mathbf{9},{ }^{45}$ and one monounsaturated fatty acid $\mathbf{1 0},{ }^{36}$ described for the first time in this species. They were characterized on the basis of chromatographic and spectroscopic methods, such as GC-MS, IR, ESI-MS, and NMR (1D and 2D), and comparison with data from the literature.

Because cassythicine (3) was isolated a long time ago, only partial ${ }^{1} \mathrm{H}$ NMR data are described in the literature. ${ }^{46}$ Therefore, this study reports the complete and unequivocal ${ }^{1} \mathrm{H}$ and ${ }^{13} \mathrm{C}$ NMR chemical shift assignments for cassythicine 3, as well as their heteronuclear ${ }^{1} \mathrm{H}-{ }^{13} \mathrm{C}$ correlations, nOe observations, and accurate ${ }^{1} \mathrm{H}-{ }^{1} \mathrm{H}$ scalar coupling constants (Table 1). The NMR data for $\mathbf{3}$ were initially collected in $\mathrm{CDCl}_{3}$ as the solvent. However, in this solvent it was too difficult to observe both ${ }^{1} \mathrm{H}$ and ${ }^{13} \mathrm{C}$ signals of the aliphatic system, probably due to a dynamic process, mainly for the aliphatic moiety, and consequently it was too difficult to identify all the signals, measure the ${ }^{1} \mathrm{H}-{ }^{1} \mathrm{H}$ coupling constants, and recognize the heteronuclear ${ }^{1} \mathrm{H}-{ }^{13} \mathrm{C}$ correlations in the HSQC and HMBC experiments. For this reason, cassythicine (3) was redissolved in methanol- $d_{4}$ and resubmitted to NMR analysis. In contrast to $\mathrm{CDCl}_{3}$, the signals were much more evident in both ${ }^{1} \mathrm{H}$ and ${ }^{13} \mathrm{C}\left\{{ }^{1} \mathrm{H}\right\}$ NMR spectra obtained in methanol- $d_{4}$ and it was possible to recognize all signals in the spectra as well as to perform all NMR chemical shift assignments and accurately measure the ${ }^{1} \mathrm{H}-{ }^{1} \mathrm{H}$ coupling constants. Moreover, by taking the NMR measurements of $\mathbf{3}$ in methanol- $d_{4}$ it was possible to observe the nuclear Overhauser effect, which was essential for the relative ${ }^{1} \mathrm{H}$ NMR chemical shift assignments of the aliphatic hydrogens. Selective irradiation of the resonance frequency of H-8 caused a nOe enhancement only in the signal of H-7 at $3.38 \mathrm{ppm}$. Selective irradiation of the resonance frequency of $\mathrm{H}-7$ at $3.38 \mathrm{ppm}$ showed a nOe enhancement in the signals of $\mathrm{H}-8, \mathrm{H}-6 \mathrm{a}$, and $\mathrm{CH}_{3}-\mathrm{N}$, whereas selective irradiation of the resonance frequency of $\mathrm{H}-7$ at 2.82 showed no nOe enhancements in the signal of $\mathrm{H}-6 \mathrm{a}$, nor in the signal of $\mathrm{CH}_{3}-\mathrm{N}$. These findings are supported by the selective irradiation of the resonance frequency of $\mathrm{CH}_{3}-\mathrm{N}$, which showed nOe intensification in the signals of H-7 at 3.38 ppm, H-6a, and both H-5s (Table 1). As for H-8, selective irradiation of the resonance frequency of $\mathrm{H}-3$ also showed nOe intensification only in the signal of H-4 at $2.99 \mathrm{ppm}$, and irradiation of H-4 at $2.99 \mathrm{ppm}$ caused a nOe enhancement in the signals of $\mathrm{H}-3$ and both $\mathrm{H}-5$. Selective irradiation of the resonance frequency of $\mathrm{H}-5$ at $3.49 \mathrm{ppm}$ showed nOe enhancement in the signals of $\mathrm{H}-4$ at $2.99, \mathrm{CH}_{3}-\mathrm{N}$, and $\mathrm{H}-6 \mathrm{a}$ (Table 1), indicating that $\mathrm{H}-7$ at $3.38, \mathrm{H}-6 \mathrm{a}, \mathrm{CH}_{3}-\mathrm{N}, \mathrm{H}-5$ at 3.49 and $\mathrm{H}-4$ at 2.99 are located on the same side of the molecule. This conclusion was supported by exploring the coupling constants (Table 1). In contrast, in the ${ }^{1} \mathrm{H}$ NMR spectrum obtained in methanol- $d_{4}$ the HO-9 signal was not evident as in $\mathrm{CDCl}_{3}$. Here, we report all NMR data obtained in both $\mathrm{CDCl}_{3}$ and methanol- $d_{4}$ for cassythicine (3), which can aid in further elucidation of the chemical structure (Table 1).

\section{Biological studies}

Acanthoic acid (1) showed anti-proliferative activity against epimastigote forms of Trypanosoma cruzi. After $96 \mathrm{~h}$ this compound considerably reduced the number of parasites, by causing progressive injury compared with untreated cells. A dose-dependent effect was observed, and at this time the $\mathrm{IC}_{50}$ value was $59 \mu \mathrm{mol} \mathrm{L}^{-1}$ (Figure 1), whereas the standard drug benznidazole showed an $\mathrm{IC}_{50}$ of $7 \mu \mathrm{mol} \mathrm{L}{ }^{-1}{ }^{17}$ Other terpene derivatives showed some trypanocidal activity, such as dehydrozaluzanin C isolated from Munnozia maronii 
Table 1. ${ }^{13} \mathrm{C}\left\{{ }^{1} \mathrm{H}\right\},{ }^{1} \mathrm{H},{ }^{1} \mathrm{H}-{ }^{13} \mathrm{C}$ HMBC, and nOe data for cassythicine $(3)^{\mathrm{a}}$

\begin{tabular}{|c|c|c|c|c|c|c|}
\hline Position & ${ }^{1} \mathrm{H} \delta$ mult. $J^{\mathrm{b}}$ & ${ }^{1} \mathrm{H} \delta$ mult. $J^{\mathrm{c}}$ & ${ }^{13} \mathrm{C}\left\{{ }^{1} \mathrm{H}\right\} \delta^{\mathrm{b}}$ & ${ }^{13} \mathrm{C}\left\{{ }^{1} \mathrm{H}\right\} \delta^{\mathrm{c}}$ & ${ }^{1} \mathrm{H}-{ }^{13} \mathrm{C} \mathrm{HMBC}{ }^{\mathrm{b}}$ & $\mathrm{nOe}^{\mathrm{d}}$ \\
\hline 1 & & & 150.1 & 147.6 & & \\
\hline 1a & & & 118.1 & 116.9 & & \\
\hline 2 & & & 144.2 & 142.3 & & \\
\hline 3 & $6.65 s$ & $6.52 s$ & 107.4 & 106.7 & $1,1 \mathrm{a}, 2,3 \mathrm{a}, 3 \mathrm{~b}, 4$ and $6 \mathrm{a}$ & Ha-4 \\
\hline $3 \mathrm{a}$ & & & 125.2 & 124.2 & & \\
\hline $3 b$ & & & 121.1 & 122.8 & & \\
\hline 4 & $\begin{array}{l}\text { a } 2.99 d d d 12.8 ; 4.6 ; 1.1 \\
\text { b } 3.27 d d d 12.9 ; 12.8 ; 6.0\end{array}$ & $\begin{array}{l}\text { a } 2.73 \text { brs } \\
\text { b } 3.38 \text { brs }\end{array}$ & 27.2 & 27.1 & $\begin{array}{l}3,3 \mathrm{a}, 3 \mathrm{~b} \text { and } 5 \\
3 \mathrm{a} \text { and } 5\end{array}$ & $\begin{array}{l}\mathrm{H}-3, \mathrm{Hb}-4, \mathrm{Ha}-5 \text { and } \mathrm{Hb}-5 \\
\mathrm{Ha}-4 \text { and } \mathrm{Hb}-5\end{array}$ \\
\hline 5 & $\begin{array}{l}\text { a } 3.49 d d d 12.9 ; 12.5 ; 4.6 \\
\text { b } 3.78 d d d 12.5 ; 6.0 ; 1.1\end{array}$ & $\begin{array}{l}\text { a } 2.92 \text { brs } \\
\text { b } 3.35 \text { brs }\end{array}$ & 54.1 & 52.8 & $\begin{array}{l}4 \text { and } 6 \mathrm{a} \\
3 \mathrm{a}, 4,6 \mathrm{a} \text { and } \mathrm{CH}_{3}-\mathrm{N}\end{array}$ & $\begin{array}{l}\mathrm{Ha}-4, \mathrm{Hb}-5, \mathrm{H}-6 \mathrm{a} \text { and } \mathrm{CH}_{3}-\mathrm{N} \\
\mathrm{Ha}-4, \mathrm{Hb}-4, \mathrm{Ha}-5 \text { and } \mathrm{CH}_{3}-\mathrm{N}\end{array}$ \\
\hline $6 a$ & $4.30 d d 14.2 ; 4.5$ & NO & 64.0 & 61.9 & $3 \mathrm{a}, 3 \mathrm{~b}, 7,7 \mathrm{a}$ and $\mathrm{CH}_{3}-\mathrm{N}$ & $\mathrm{Ha}-5, \mathrm{Hb}-7$ and $\mathrm{CH}_{3}-\mathrm{N}$ \\
\hline 7 & $\begin{array}{l}\text { a } 2.82 d d 14.2 ; 13.8 \\
\text { b } 3.38 d d 13.8 ; 4.5\end{array}$ & $\begin{array}{l}\text { a } 2.96 \mathrm{brs} \\
\text { b } 3.11 \mathrm{brs}\end{array}$ & 31.9 & 32.3 & $\begin{array}{l}3 \mathrm{~b}, 6 \mathrm{a}, 7 \mathrm{a}, 8 \text { and } 11 \mathrm{a} \\
3 \mathrm{~b}, 6 \mathrm{a}, 7 \mathrm{a}, 8 \text { and } 11 \mathrm{a}\end{array}$ & $\begin{array}{l}\mathrm{Hb}-7 \\
\mathrm{H}-6 \mathrm{a}, \mathrm{Ha}-7, \mathrm{H}-8 \text { and } \mathrm{CH}_{3}-\mathrm{N}\end{array}$ \\
\hline $7 \mathrm{a}$ & & & 126.4 & 127.2 & & \\
\hline 8 & $6.82 s$ & $6.80 s$ & 116.4 & 114.5 & $1 \mathrm{a}, 7,9,10,11$ and $11 \mathrm{a}$ & $\mathrm{Hb}-7$ \\
\hline 9-OH & NO & $8.54 b r s$ & 148.2 & 145.6 & $8^{*}, 9^{*}$ and $10^{*}$ & \\
\hline 10 & & & 148.6 & 145.7 & & \\
\hline 11 & $7.68 s$ & $7.60 s$ & 112.0 & 110.0 & $1 \mathrm{a}, 7,7 \mathrm{a}, 8,9,10$ and $11 \mathrm{a}$ & \\
\hline $11 \mathrm{a}$ & & & 122.8 & 122.5 & & \\
\hline $\mathrm{CH}_{3}-\mathrm{N}$ & $3.17 s$ & $2.76 s$ & 42.0 & 42.1 & 5 and $6 a$ & $\mathrm{Ha}-5, \mathrm{Hb}-5, \mathrm{H}-6 \mathrm{a}$ and $\mathrm{Hb}-7$ \\
\hline $\mathrm{CH}_{3}-\mathrm{O}$ & $3.87 s$ & $3.90 s$ & 56.6 & 56.2 & 10 & $\mathrm{H}-11$ \\
\hline $\mathrm{O}-\mathrm{CH}_{2}-\mathrm{O}$ & $\begin{array}{l}\text { a } 6.00 d 1.1 \\
\text { b } 6.15 d 1.1\end{array}$ & $\begin{array}{l}\text { a } 5.94 d 1.4 \\
\text { b } 6.10 d 1.4\end{array}$ & 102.9 & 101.0 & $\begin{array}{l}1 \text { and } 2 \\
1 \text { and } 2\end{array}$ & \\
\hline
\end{tabular}

aThe experiments were performed at $295 \mathrm{~K}$ at 400 and $100 \mathrm{MHz}$ for ${ }^{1} \mathrm{H}$ and ${ }^{13} \mathrm{C}$, and all NMR chemical shifts are given in ppm related to TMS signal at $0.00 \mathrm{ppm}$ as internal reference and coupling constants $(J)$ in $\mathrm{Hz}$. ${ }^{b}$ Data obtained in $\mathrm{CD}_{3} \mathrm{OD}$. ${ }^{\mathrm{c}} \mathrm{Data}$ obtained in $\mathrm{CDCl}_{3}$. ${ }^{\mathrm{d}} 1 \mathrm{D}$ nOe obtained by selective excitation of each hydrogen in the second table column. $\mathrm{NO}=$ Not Observed. $*$ Correlations observed in the experiment obtained in $\mathrm{CDCl}_{3}$.

(Asteraceae), that showed $\mathrm{IC}_{90}$ between $10-205 \mu \mathrm{mol} \mathrm{L}{ }^{-1}$ against different strains of T. cruzi. ${ }^{48}$

The potential toxic effect of $\mathbf{1}$ on the $\mathrm{LLCMK}_{2}$ cell line was also evaluated. After $96 \mathrm{~h}$ of treatment, the $50 \%$ cytotoxic concentration was $347 \mu \mathrm{mol} \mathrm{L}^{-1}$ (Figure 2). Therefore, by the selectivity index (SI) ratio $\left(\mathrm{CC}_{50}\right.$ for $\mathrm{LLCMK}_{2} / \mathrm{IC}_{50}$ for

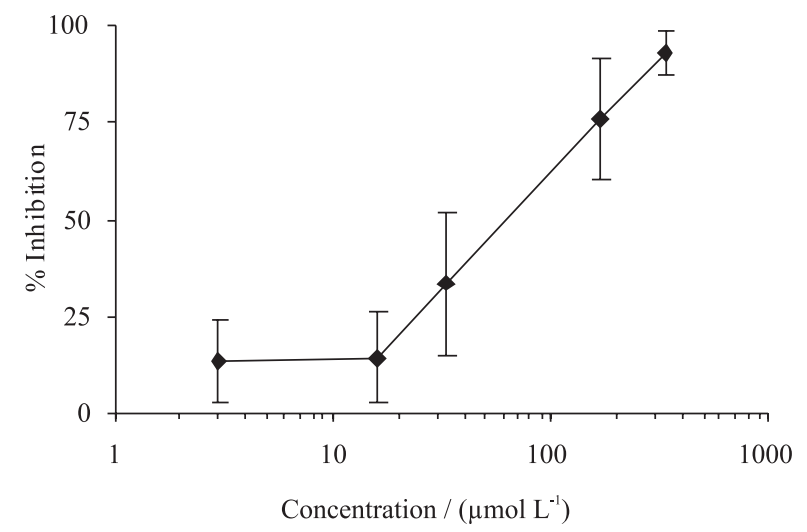

Figure 1. Effect of acanthoic acid (1) on the proliferation of epimastigote forms of Trypanosoma cruzi. The parasite was cultured in LIT medium at $28^{\circ} \mathrm{C}$ for $96 \mathrm{~h}$. Values are the mean of three independent experiments. parasite), acanthoic acid (1) was more selective against the parasite than against mammal cells, with a SI of 5.9.

Because of the present inefficient chemotherapy available for Chagas' disease, new active compounds need to be found, and natural products may play an important role. Some previous studies have demonstrated the

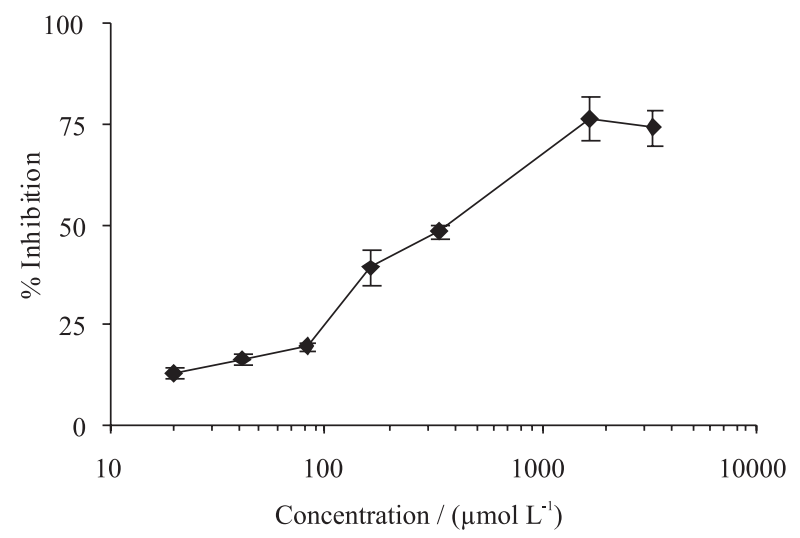

Figure 2. Toxic effect of acanthoic acid (1) on the $\mathrm{LLCMK}_{2}$ cell line after $96 \mathrm{~h}$ of treatment. The cells were cultured in DMEM medium. Values are the mean of two independent experiments. 
therapeutic potential of compounds derived from natural sources. ${ }^{16,48-49}$ Several synthetic compounds have also shown trypanocidal activity. ${ }^{50,51}$

Acanthoic acid (1) at $3 \mu \mathrm{mol} \mathrm{L}^{-1}$ (the lowest concentration tested) displayed a growth inhibition of parasites of $13.6 \%$, while at the highest concentration $\left(331 \mu \mathrm{mol} \mathrm{L}^{-1}\right)$, over $90 \%$ of the cells were affected. Therefore, the 50\% inhibition concentration was determined at $59 \mu \mathrm{mol} \mathrm{L}^{-1}$. In contrast, the toxic effect on mammalian cells occurs only in high concentrations, with a $\mathrm{CC}_{50}$ of $347 \mu \mathrm{mol} \mathrm{L}^{-1}$, showing that $\mathbf{1}$ is 5.9 times more toxic to the epimastigote forms of T. cruzi than the $\operatorname{LLCMK}_{2}$ cell line.

\section{Conclusions}

Our results demonstrate that Annona amazonica, in addition to containing alkaloids, a class of compounds typically found in species of the family Annonaceae, produces as its major secondary metabolite, the pimaradienetype diterpene, acanthoic acid (1). Therefore, this plant is a new renewable natural source of this promising compound for drug development. Knowledge of the medicinal potential of $\mathbf{1}$ was augmented by demonstrating its trypanocidal activity, together with its low toxicity. In addition, the complete and unequivocal ${ }^{1} \mathrm{H}$ and ${ }^{13} \mathrm{C}$ NMR chemical shift assignments for cassythicine are now available.

\section{Acknowledgments}

The authors are grateful to Prof. Dr. A.C. Webber from the Universidade Federal do Amazonas (UFAM), Brazil, for botanical identification; as well as to CAPES, CNPq, FAPESP, FINEP, and the RENOR Project for financial support and fellowships.

\section{Supplementary Information}

Supplementary information containing 1D and 2D NMR and MS data is available free of charge at http://jbcs.sbq.org.br as a PDF file.

\section{References}

1. Chatrou, L. W.; Rainer, H.; Maas, P. J. M. Annonaceae (Soursop Family). In: Smith, N.; Mori, S. A.; Henderson, A.; Stevenson, D. W.; Heald, S. V. (eds.). Flowering Plants of the Neotropics. The New York Botanical Garden, New York, pp. 18-20, 2004.

2. Corrêa, M. P.; Dicionário das Plantas Úteis do Brasil e das Exóticas Cultivadas, IBDF: Rio de Janeiro, Brasil, 1984.

3. Maas, P. J. M.; Kamer, H. M.; Junikka, L.; Mello-Silva, R.; Rainer, H.; Rodriguésia 2001, 52, 61.
4. Leboeuf, M.; Cavé, A.; Bhaumik, P. K.; Mukherjee, B.; Mukherjee, R.; Phytochemistry 1982, 21, 2783.

5. Rupprecht, J. K.; Hui, Y. -H.; McLaughlin, J. L.; J. Nat. Prod. 1990, 53, 237.

6. Likhitwitayawuid, K.; Angerhofer, C. K.; Chai, H.; Pezzuto, J. M.; Cordell, G. A.; J. Nat. Prod. 1993, 56, 1468.

7. Alali, F. Q.; Liu, X. -X.; McLaughlin, J. L.; J. Nat. Prod. 1999, $62,504$.

8. Campos, F. R.; Batista, R. L.; Batista, C. L.; Costa, E. V.; Barison, A.; Santos, A. G.; Pinheiro, M. L. B.; Biochem. Syst. Ecol. 2008, 36, 804.

9. Costa, E. V.; Pinheiro, M. L. B.; Xavier, C. M.; Silva, J. R. A.; Amaral, A. C. F.; Souza, A. D. L.; Barison, A.; Campos, F. R.; Ferreira, A. G.; Machado, G. M. C.; Leon, L. L. P.; J. Nat. Prod. 2006, 69, 292.

10. Costa, E. V.; Teixeira, S. D.; Marques, F. A.; Duarte, M. C. T.; Delarmelina, C.; Pinheiro, M. L. B.; Trigo, J. R.; Maia, B. H. L. N. S.; Phytochemistry 2008, 69, 1895.

11. Boyom, F. F.; Ngouana, V.; Zollo, P. H. A.; Menut, C.; Bessiere, J. M.; Gut, J.; Rosenthal, P. J.; Phytochemistry 2003, 64, 1269.

12. Queiroz, E. F.; Roblot, F.; Cavé, A.; Paulo, M. Q.; Fournet, A.; J. Nat. Prod. 1996, 59, 438.

13. Maas, P. J. M.; Maas, H.; Miralha, J. M. S.; Junikka, L.; Rodriguésia 2007, 58, 617.

14. Thomsen, K.; Brimer, L.; Bot. J. Linnaeus Soc. 1997, 124, 273.

15. Adams, R. P.; Identification of Essential Oil Components by Gas Chromatography/Quadrupole Mass Spectroscopy, Allured Publ. Corp.: Carol Stream, IL, USA, 2001.

16. Luize, P. S.; Nakamura-Ueda, T.; Dias-Filho, B. P.; Cortez, D. A. G.; Nakamura, C. V.; Biol. Pharm. Bull. 2006, 10, 2126.

17. Skehan, P.; Storeng, R.; Scudiero, D.; Monks, A.; McMahon, J.; Vistica, D.; Warren, J. T.; Bokesh, H.; Boyd, M. R.; J. Natl. Cancer Inst. 1990, 82, 1107.

18. Kim, Y. H.; Chung, B. S.; J. Nat. Prod. 1988, 51, 1080.

19. Nunez, C. V.; Amêndola, M. C.; Lago, J. H. G.; Roque, N. F.; Biochem. Syst. Ecol. 2004, 32, 233.

20. Jayasuriya, H.; Herath, K. B.; Ondeyka, J. G.; Guan, Z.; Borris, R. P.; Tiwari, S.; Jong, W.; Chavez, F.; Moss, J.; Stevenson, D. W.; Beck, H. T.; Slattery, M.; Zamora, N.; Schulman, M.; Ali, A.; Sharma, N.; MacNaul, K.; Hayes, N.; Menke, J. G.; Singh, S. B.; J. Nat. Prod. 2005, 68, 1247.

21. Pyun, K. H.; Choi, I.; Kang, H. S.; Lee, J. J.; Kim, Y. H.; PCT Int. Appl. WO 1995034300, 1995.

22. Kang, H. S.; Kim, Y. -H.; Lee, C. S.; Lee, J. J.; Choi, I. Pyun, K. H.; Cell. Immunol. 1996, 170, 212.

23. Camussi, G.; Lupin, E.; Drugs 1998, 55, 613.

24. Cai, X. F.; Sehn, G.; Dat, N. T.; Kang, O. H.; Kim, J. A.; Lee, Y. M.; Lee, J. J.; Kim, Y. H.; Chem. Pharm. Bull. 2003, 51, 605.

25. Szekanecz, Z.; Koch, A. E.; Kunkel, S. L.; Strieter, R. M.; Drugs Aging 1998, 12, 377. 
26. Ling, T.; Chowdhury, C.; Kramer, B. A.; Vong, B. G.; Palladino, M. A.; Theodorakis, E. A.; J. Org. Chem. 2001, 66, 8843.

27. Park, E. -J.; Zhao, Y. -Z.; Kim, Y. H.; Lee, J. J.; Sohn, D. H. Planta Med. 2004, 70, 321.

28. Kim, J. -A.; Kim, D. -K.; Tae, J.; Kang, O. -H.; Choi, Y. -A.; Choi, S. -C.; Kim, T. -H.; Nah, Y. -H.; Choi, S. -J.; Kim, Y. -H.; Bae, K. -H.; Lee, Y. -M.; Clin. Chim. Acta 2004, 342, 193.

29. Suh, Y. -G.; Lee, K. -O.; Moon, S. -H.; Seo, S. -Y.; Lee, Y. -S.; Kim, S. -H.; Paek, S. -M.; Kim, Y. -H.; Lee, Y. -S.; Jeong, J. M.; Lee, S. J.; Kim, S. G.; Bioorg. Med. Chem. Lett. 2004, 14 , 3487.

30. Kang, O. -H.; Choi, Y. -A.; Park, H. -J.; Kang, C. -S.; Song, B. -S.; Choi, S. -C.; Nah, Y. -H.; Yun, K. -J.; Cai, X. -F.; Kim, Y. -H.; Bae, K. -H.; Lee, Y. -M.; J. Ethnopharmacol. 2006, $105,326$.

31. Na, M.; Oh, W. K.; Kim, Y. H.; Cai, X. F. Kim, S.; Kim, B. Y.; Ahn, J. S.; Bioorg. Med. Chem. Lett. 2006, 16, 3061.

32. Jung, H. J.; Shim, J. S.; Suh, Y. -G.; Kim, Y. -M.; Onu, M.; Kwon, H. J.; Cancer Sci. 2007, 98, 1943.

33. Traves, P. G.; Hortelano, S.; Zeini, M.; Chao, T. -H.; Lam, T.; Neuteboom, S. T.; Teodorakis, E. A.; Palladino, M. A.; Castrillo, A.; Bosca, L.; Mol. Pharmacol. 2007, 71, 1545.

34. Lam, T.; Ling, T.; Chowdhury, C.; Chao, T.-H.; Bahjat, F. R.; Lloyd, G. K.; Moldawer, L. L.; Palladino, M. A.; Theodorakis, E. A.; Bioorg. Med. Chem. Lett. 2003, 13, 3217.

35. Palladino, M. A.; Teodorakis, E. A.; Macherla, V. R. R.; Chao, T. -H.; Suh, Y. G.; PCT Int. Appl. WO 2007015757, 2007.

36. Wele, A.; Ndoye, I.; Badiane, M.; Nig. J. Nat. Prod. Med. 2004, 8,62 .

37. Guinaudeau, H.; Leboeuf, M.; Cavé, A.; Lloydia 1975, 38, 275.

38. Guinaudeau, H.; Leboeuf, M.; Cavé, A.; J. Nat. Prod. 1979, 42, 325.
39. Guinaudeau, H.; Leboeuf, M.; Cavé, A.; J. Nat. Prod. 1983, 46, 761.

40. Guinaudeau, H.; Leboeuf, M.; Cavé, A.; J. Nat. Prod. 1994, 57, 1033.

41. Harbone, J. B.; Baxter, H.; Moss, G. P.; Phytochemical Dictionary: A Handbook of Bioactive Compounds from Plants, $2^{\text {nd }}$ ed., CRC Press: London, 1999.

42. Jumana, S.; Hassan, C. M.; Rashid, M. A.; Biochem. Syst. Ecol. 2000, 28, 483.

43. Guinaudeau, H.; Leboeuf, M.; Cavé, A.; J. Nat. Prod. 1988, 51, 389.

44. Moreira, I. C.; Roque, N. F.; Contini, K.; Lago, J. H. G.; Rev. Bras. Farmacogn. 2007, 17, 55.

45. Chang, Y. -C.; Chang, F. -R.; Wu, Y. -C.; J. Chin. Chem. Soc. 2000, 47, 373.

46. Tewari, S.; Bhakuni, D. S.; Dhar, M. M.; Phytochemistry 1972, $11,1149$.

47. Izumi, E.; Morello, L. G.; Ueda-Nakamura, T.; Yamada-Ogatta, S. F.; Dias-Filho, B. P.; Cortez, D. A. G.; Ferreira, I. C.; Morgado-Díaz, J. A.; Nakamura, C. V.; Exp. Parasitol. 2008, $118,324$.

48. Fournet, A.; Muñoz, V.; Roblot, F.; Hocquemiller, R.; Cavé, A.; Phytother. Res. 1993, 7, 111.

49. Dantas, A. P.; Salomão, K.; Barbosa, H. S.; Castro, S. L.; Mem. Inst. Oswaldo Cruz 2006, 101, 207.

50. Bisaggio, D. F. R.; Adade, C. M.; Souto-Padrón, T.; Int. J. Antimicrob. Agents 2008, 31, 282.

51. Valdez, R. H.; Tonin, L. T. D.; Ueda-Nakamura, T.; Filho, B. P. D.; Morgado-Diaz, J. A.; Sarragiotto, M. H.; Nakamura, C. V.; Acta Trop. 2009, 110, 7.

Received: January 31, 2009 Web Release Date: June 26, 2009 


\section{Acanthoic Acid and other Constituents from the Stem of Annona amazonica (Annonaceae)}

Maria Lúcia B. Pinheiro, ${ }^{* a}$ Clahildek M. Xavier, ${ }^{a}$ Afonso D. L. de Souza, ${ }^{a}$ Diego de Moura Rabelo, ${ }^{a}$ Cristiane L. Batista, ${ }^{b}$ Regiane L. Batista, ${ }^{b}$ Emmanoel V. Costa, ${ }^{b}$ Francinete R. Campos, ${ }^{b}$ Andersson Barison, ${ }^{b}$ Rodrigo H. Valdez, ${ }^{c}$ Tânia Ueda-Nakamura ${ }^{c}$ and Celso V. Nakamura ${ }^{c}$

${ }^{a}$ Departamento de Química, Universidade Federal do Amazonas, 69077-000 Amazonas-AM, Brazil

${ }^{b}$ Departamento de Química, Centro Politécnico, Universidade Federal do Paraná, 81530-900 Curitiba-PR, Brazil 'Departamento de Análises Clinicas, Universidade Estadual de Maringá, 87020-900 Maringá-PR, Brazil

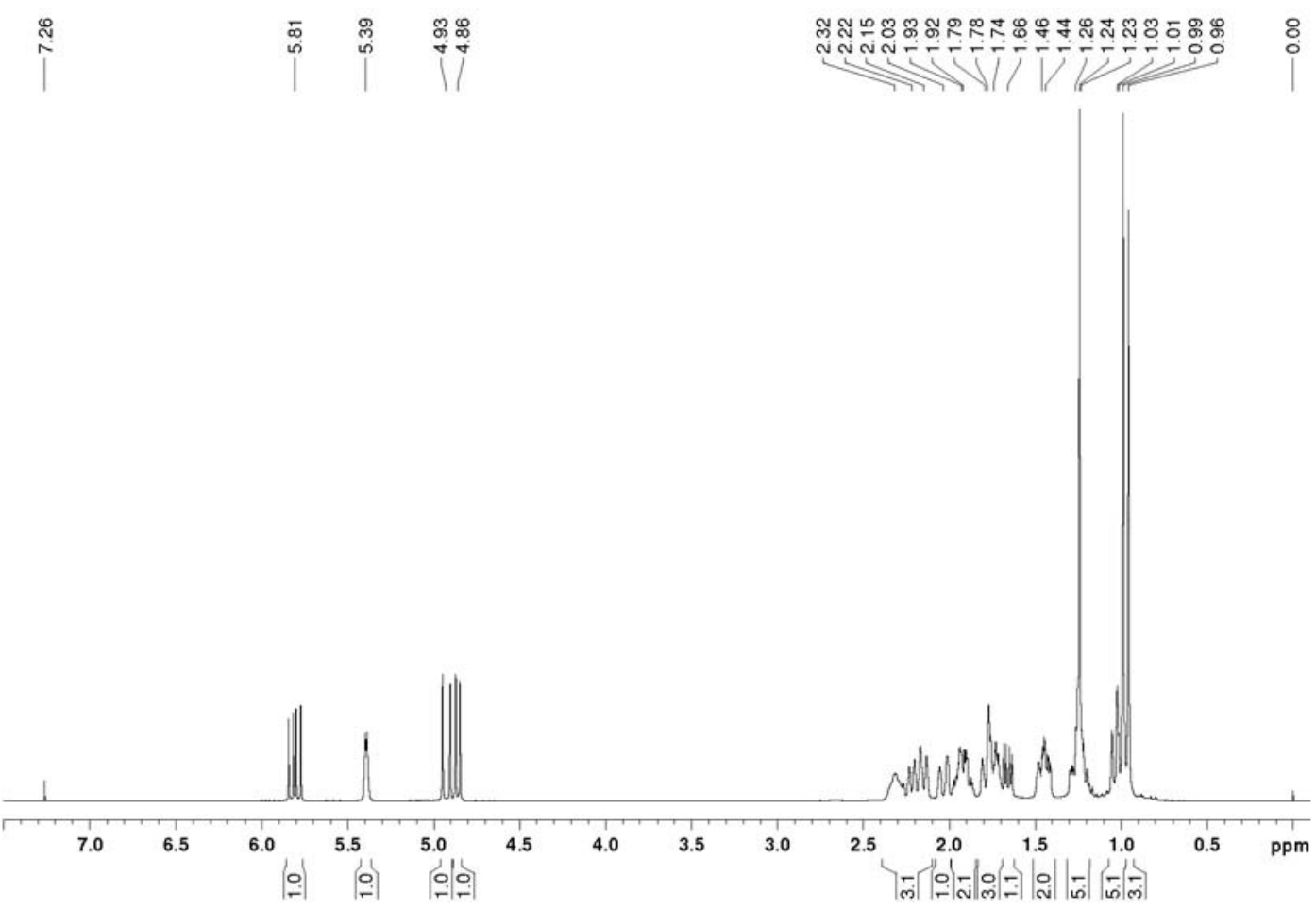

Figure S1. ${ }^{1} \mathrm{H}$ NMR spectrum of acanthoic acid in $\mathrm{CDCl}_{3}$ at $400 \mathrm{MHz}$.

*e-mail: lbelem@ufam.edu.br 


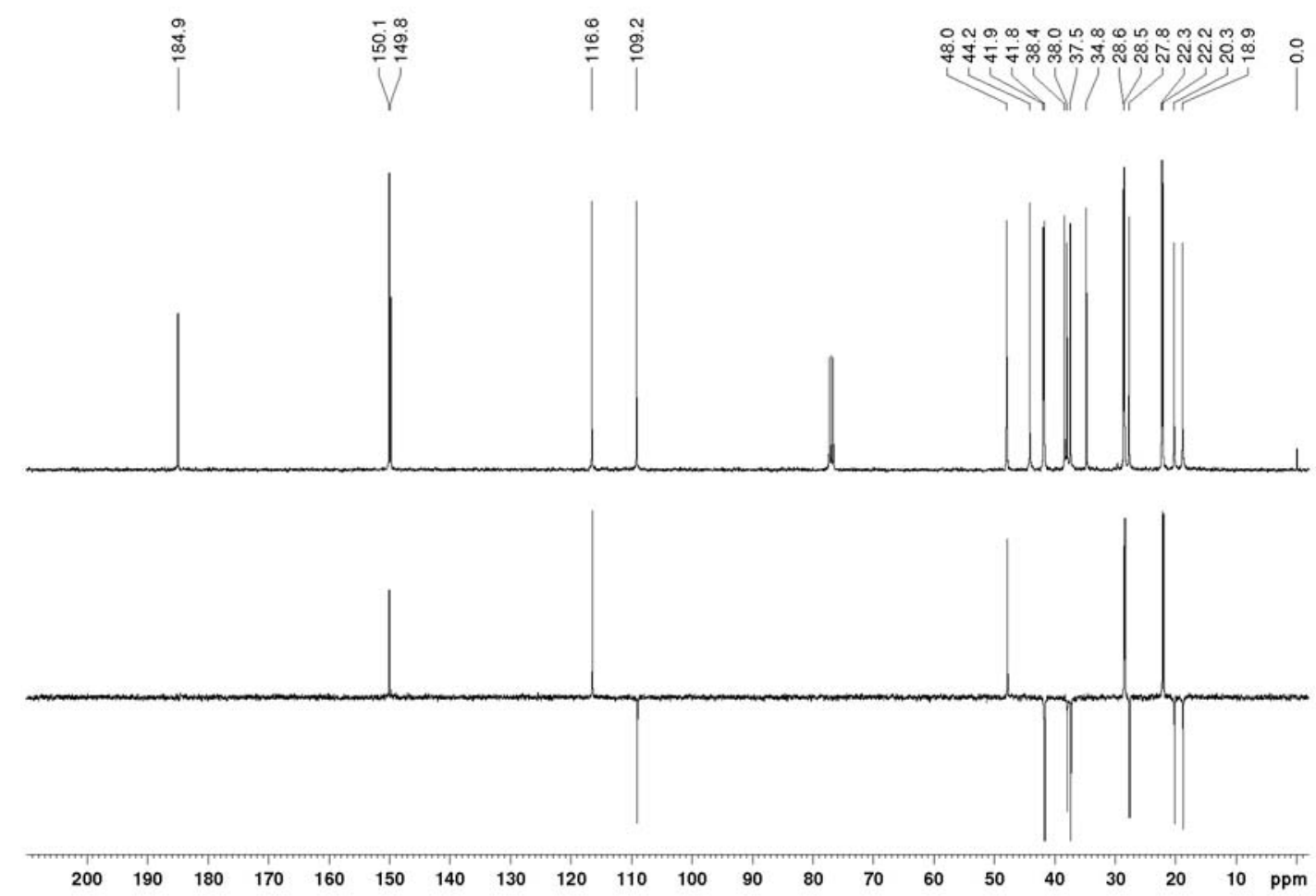

Figure S2. ${ }^{13} \mathrm{C}\left\{{ }^{1} \mathrm{H}\right\}$ and DEPT $135 \mathrm{NMR}$ spectra of acanthoic acid in $\mathrm{CDCl}_{3}$ at $100 \mathrm{MHz}$.

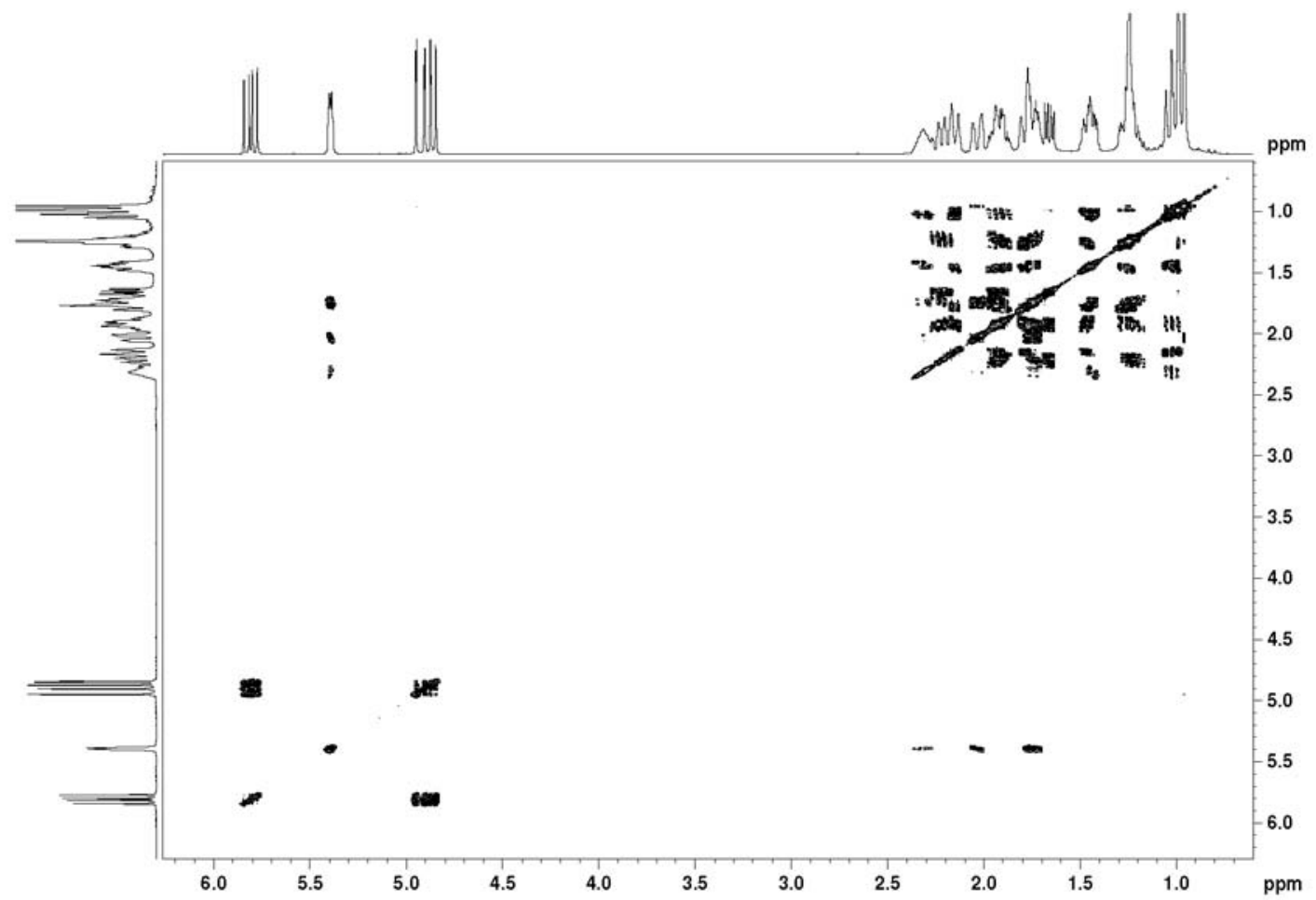

Figure S3. ${ }^{1} \mathrm{H}-{ }^{1} \mathrm{H}$ correlation map from the COSY NMR experiment on acanthoic acid in $\mathrm{CDCl}_{3}$ at $400 \mathrm{MHz}$. 


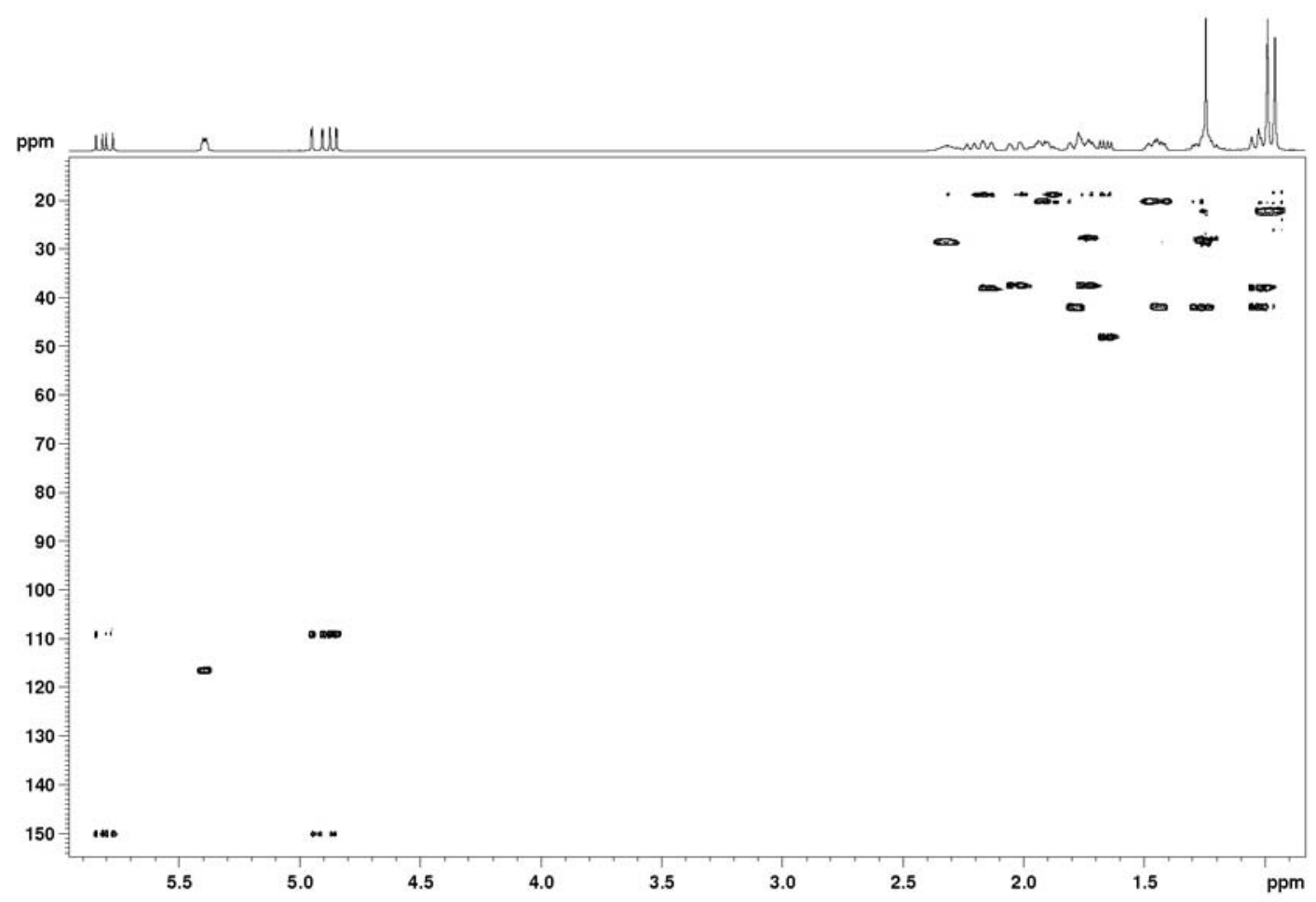

Figure S4. ${ }^{1} \mathrm{H}-{ }^{13} \mathrm{C}$ one-bond correlation map from the HSQC NMR experiment on acanthoic acid in $\mathrm{CDCl}_{3}$ at 400 and $100 \mathrm{MHz}$.

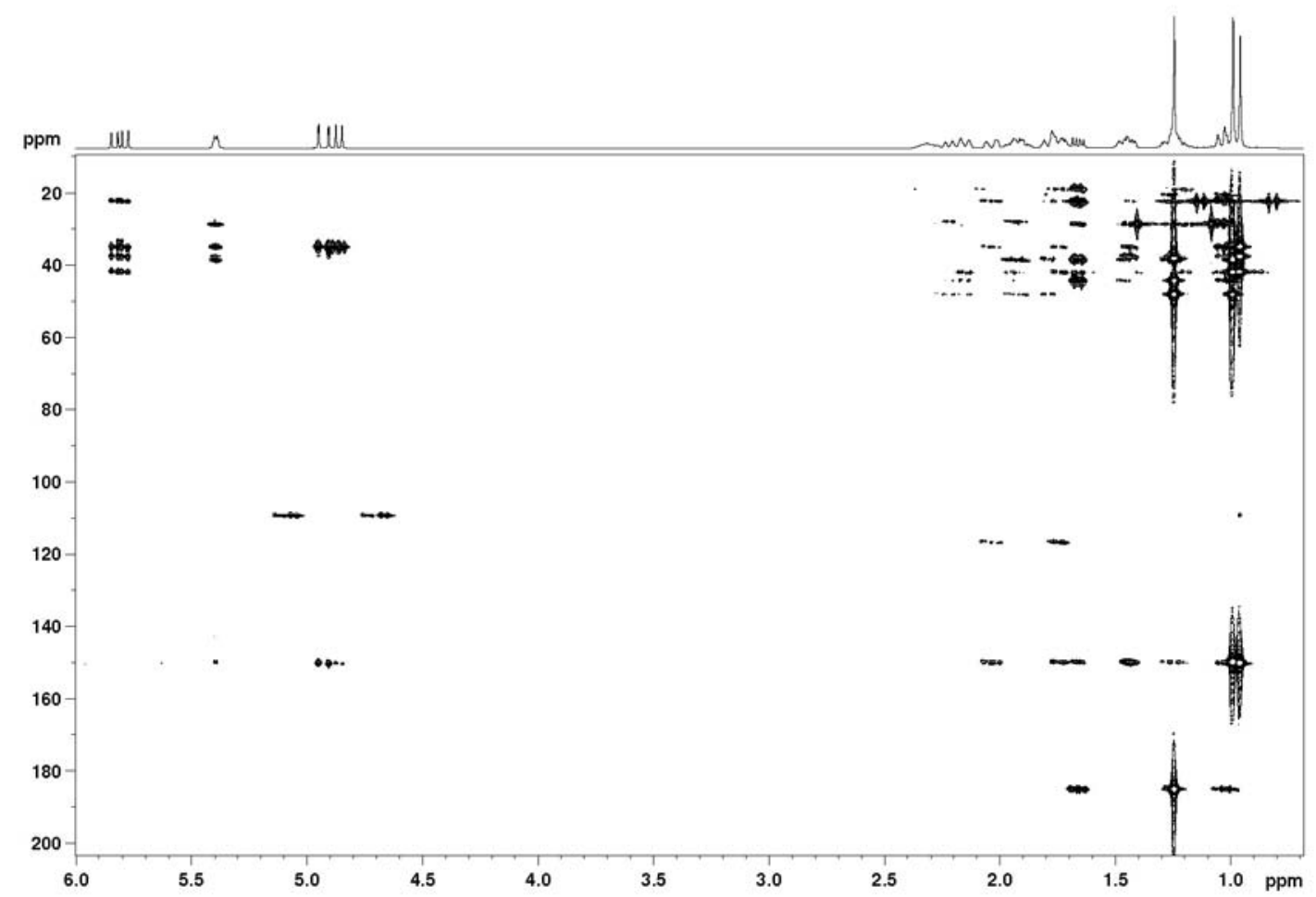

Figure S5. ${ }^{1} \mathrm{H}-{ }^{13} \mathrm{C}$ long-range correlation map from the $\mathrm{HMBC}$ NMR experiment on acanthoic acid in $\mathrm{CDCl}_{3}$ at 400 and $100 \mathrm{MHz}$. 


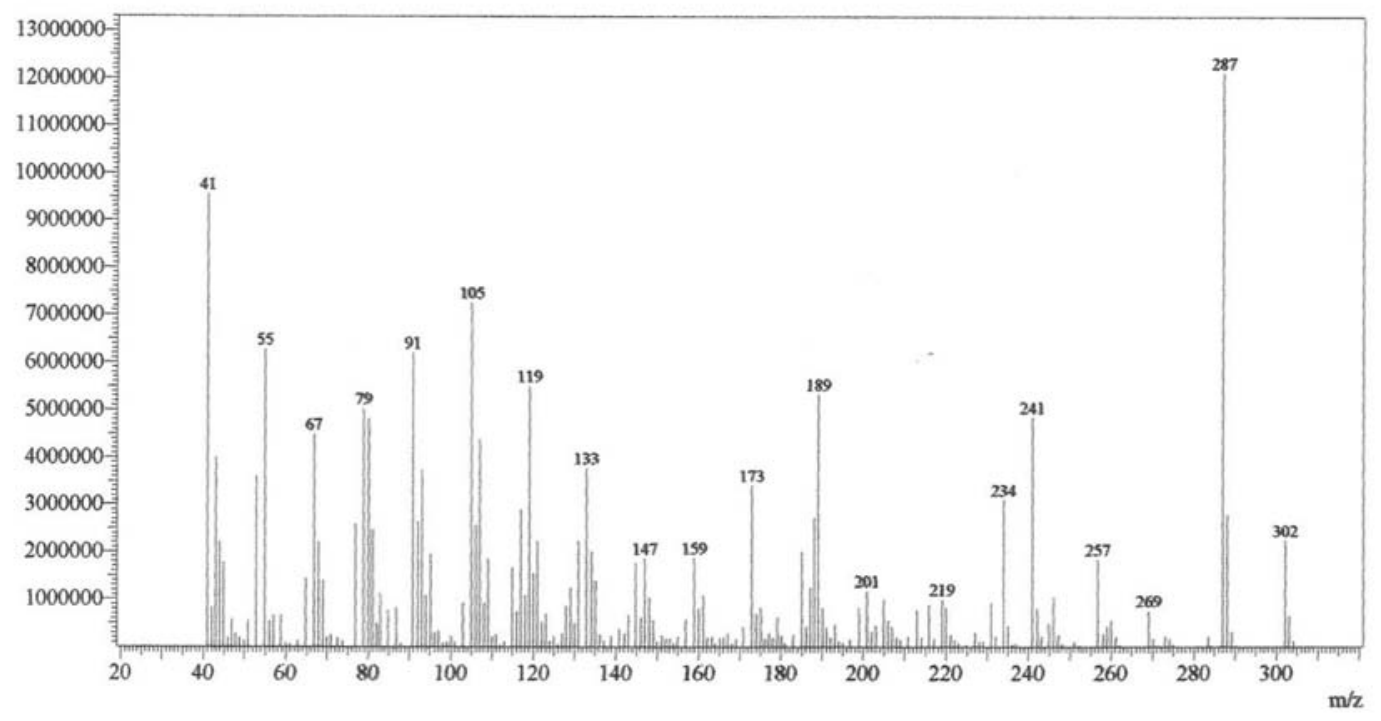

Figure S6. EI-MS of acanthoic acid.

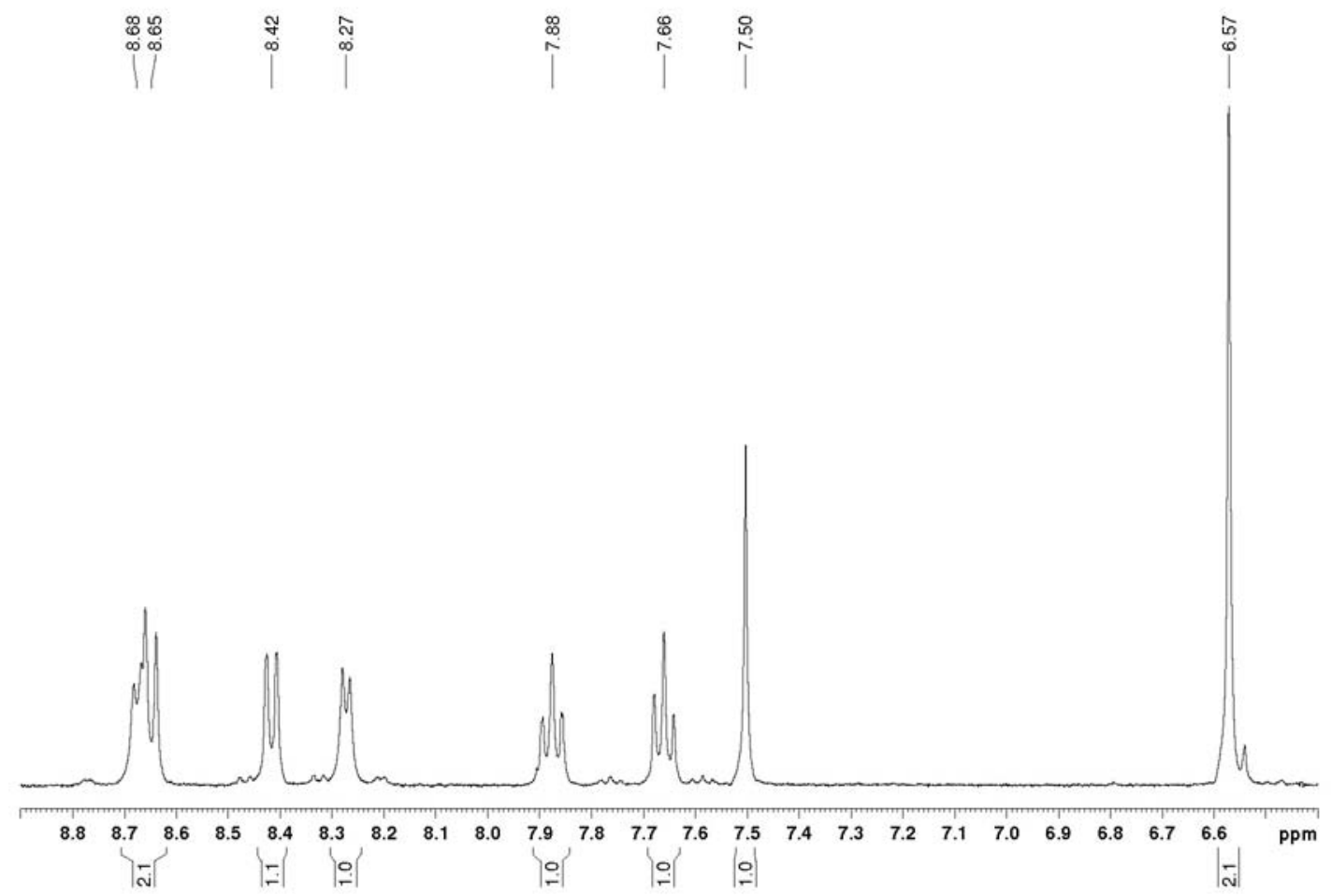

Figure S7. ' $\mathrm{H}$ NMR spectrum of liriodenine in MeOD- $d_{4}$ at $400 \mathrm{MHz}$. 


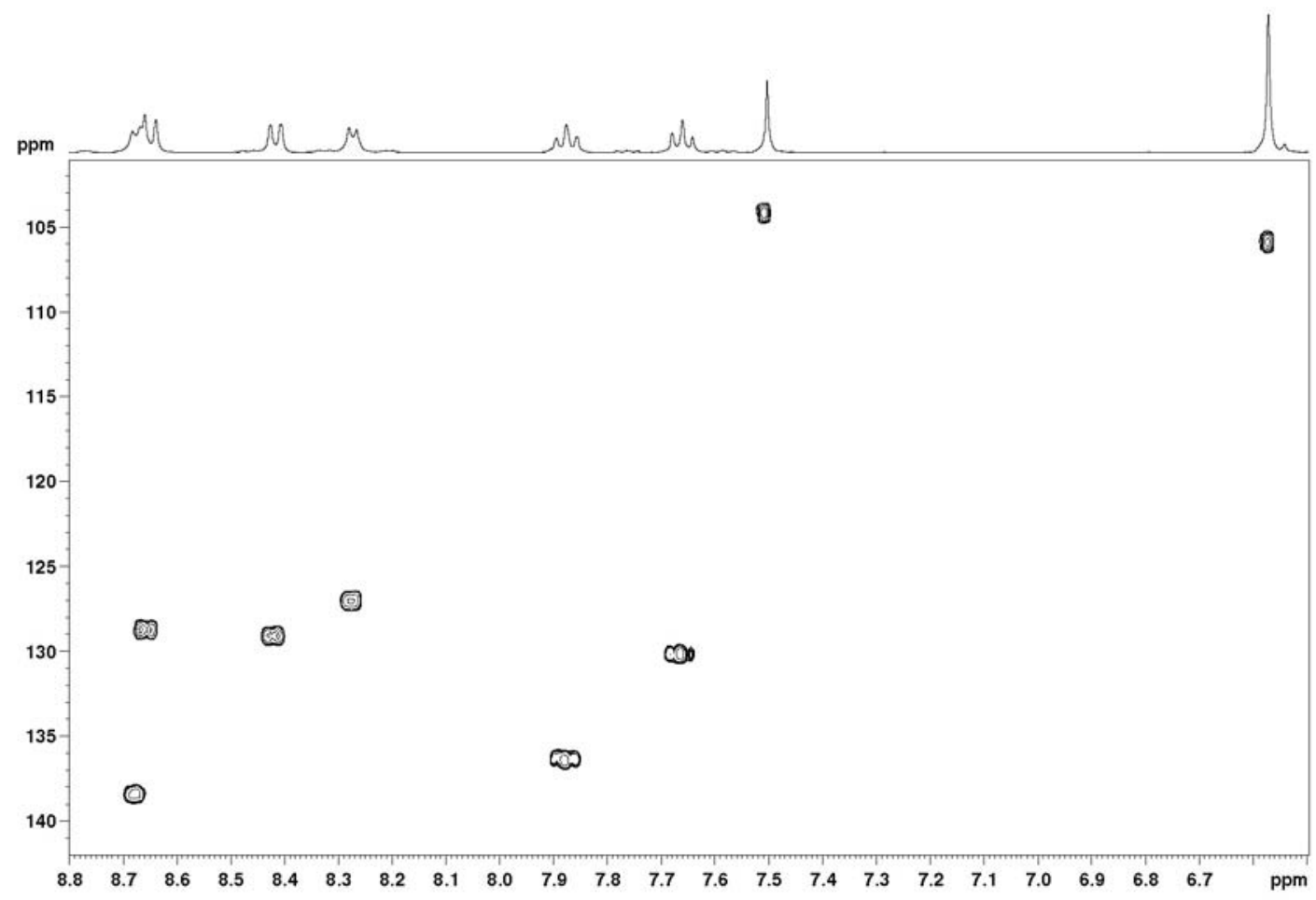

Figure S8. ${ }^{1} \mathrm{H}-{ }^{13} \mathrm{C}$ one-bond correlation map from the HSQC NMR experiment on liriodenine in MeOD- $d_{4}$ at 400 and $100 \mathrm{MHz}$.

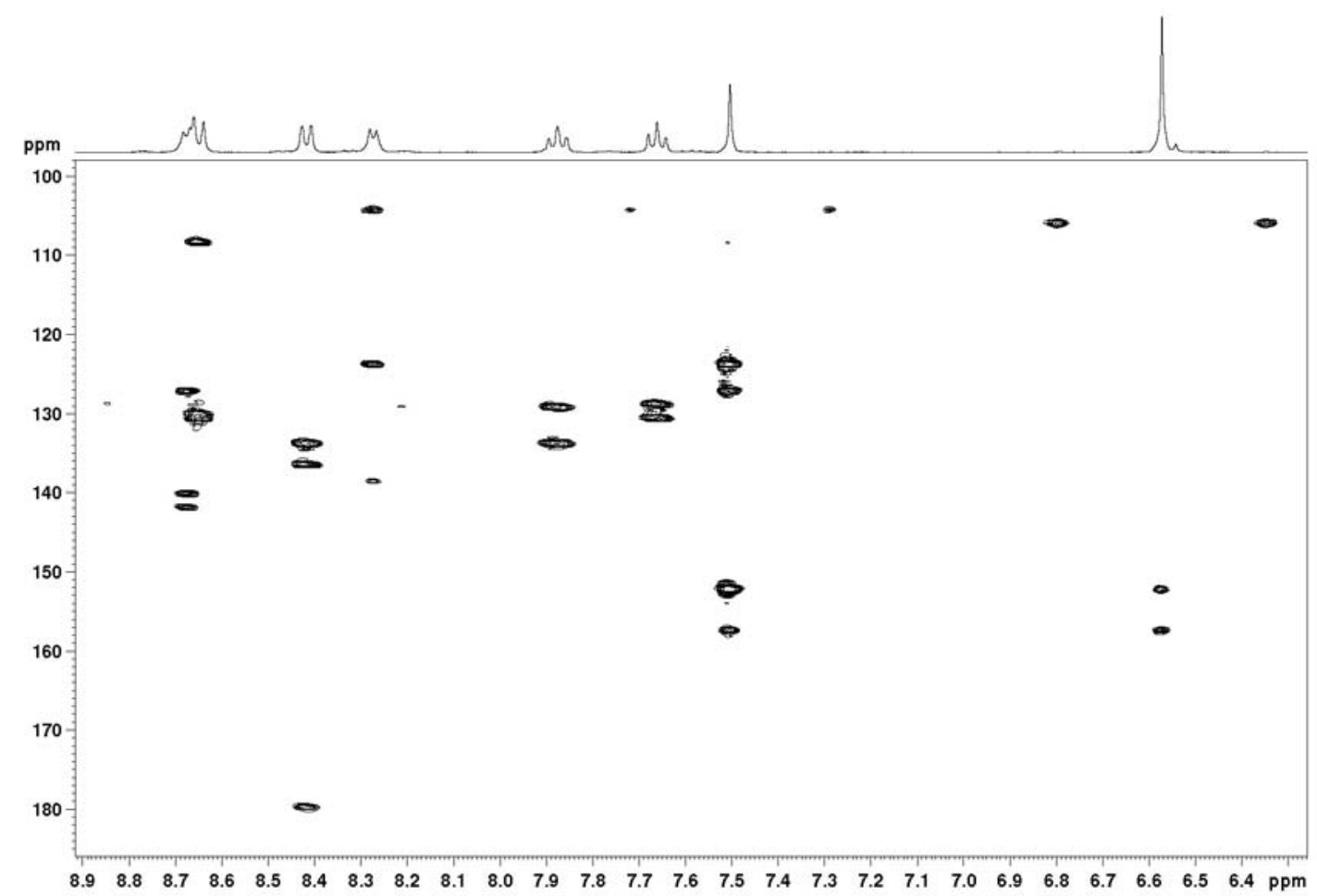

Figure S9. ${ }^{1} \mathrm{H}-{ }^{13} \mathrm{C}$ long-range correlation map from the HMBC NMR experiment on liriodenine in MeOD- $d_{4}$ at 400 and $100 \mathrm{MHz}$. 


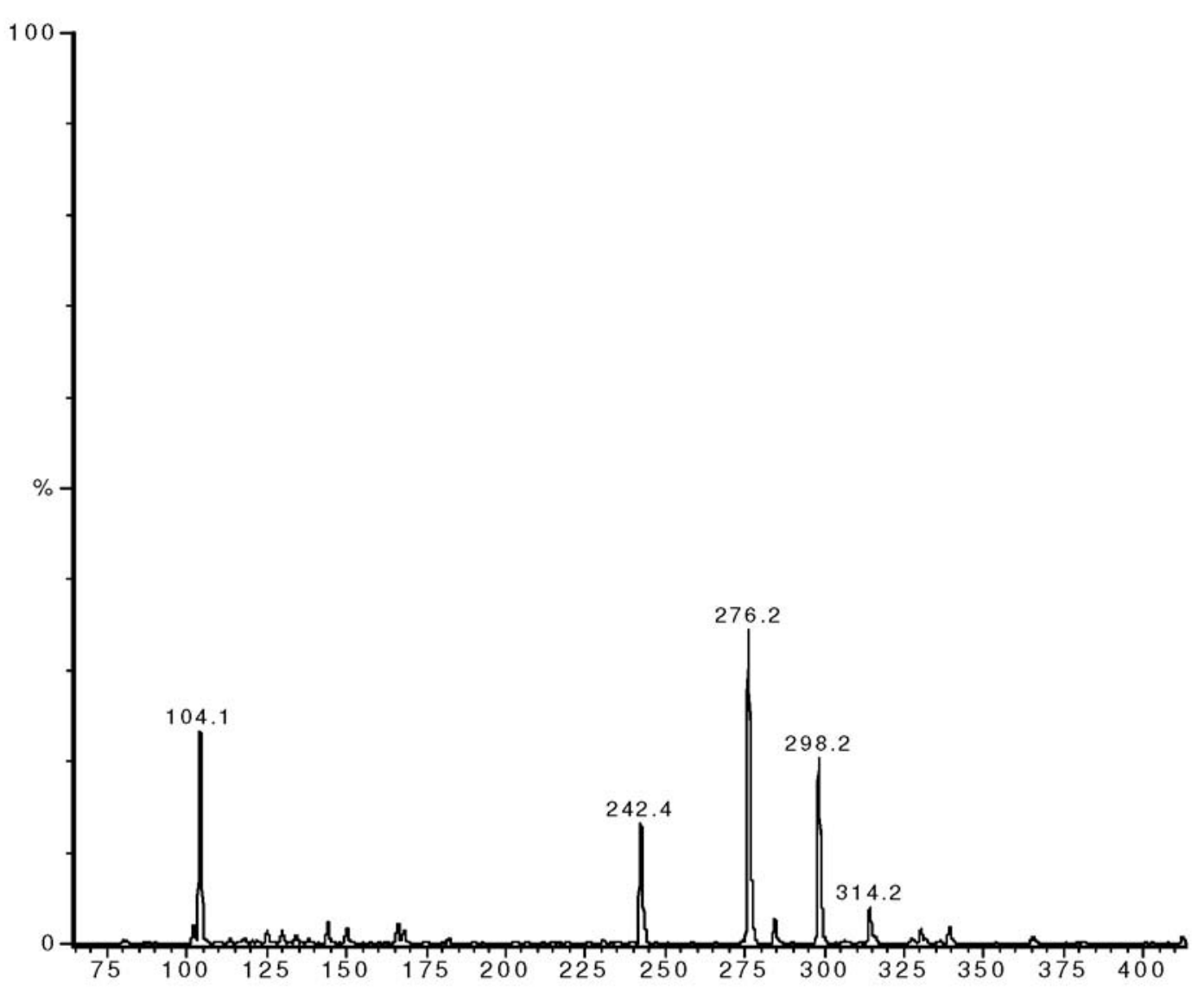

Figure S10. ESI-MS of liriodenine in $\mathrm{MeOH}$, positive mode.

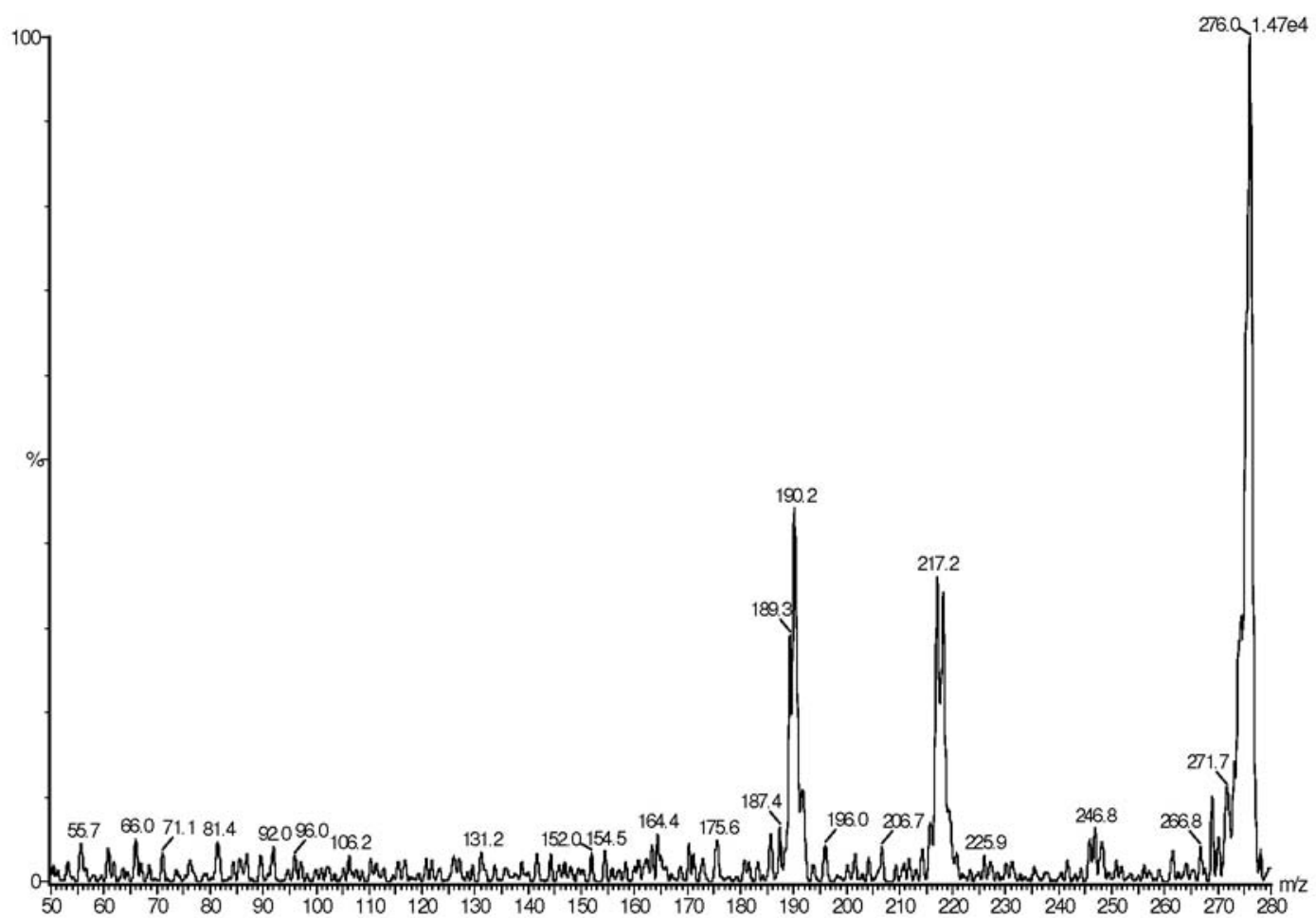

Figure S11. ESI-MS/MS of liriodenine in $\mathrm{MeOH}$, positive mode at $50 \mathrm{eV}$. 


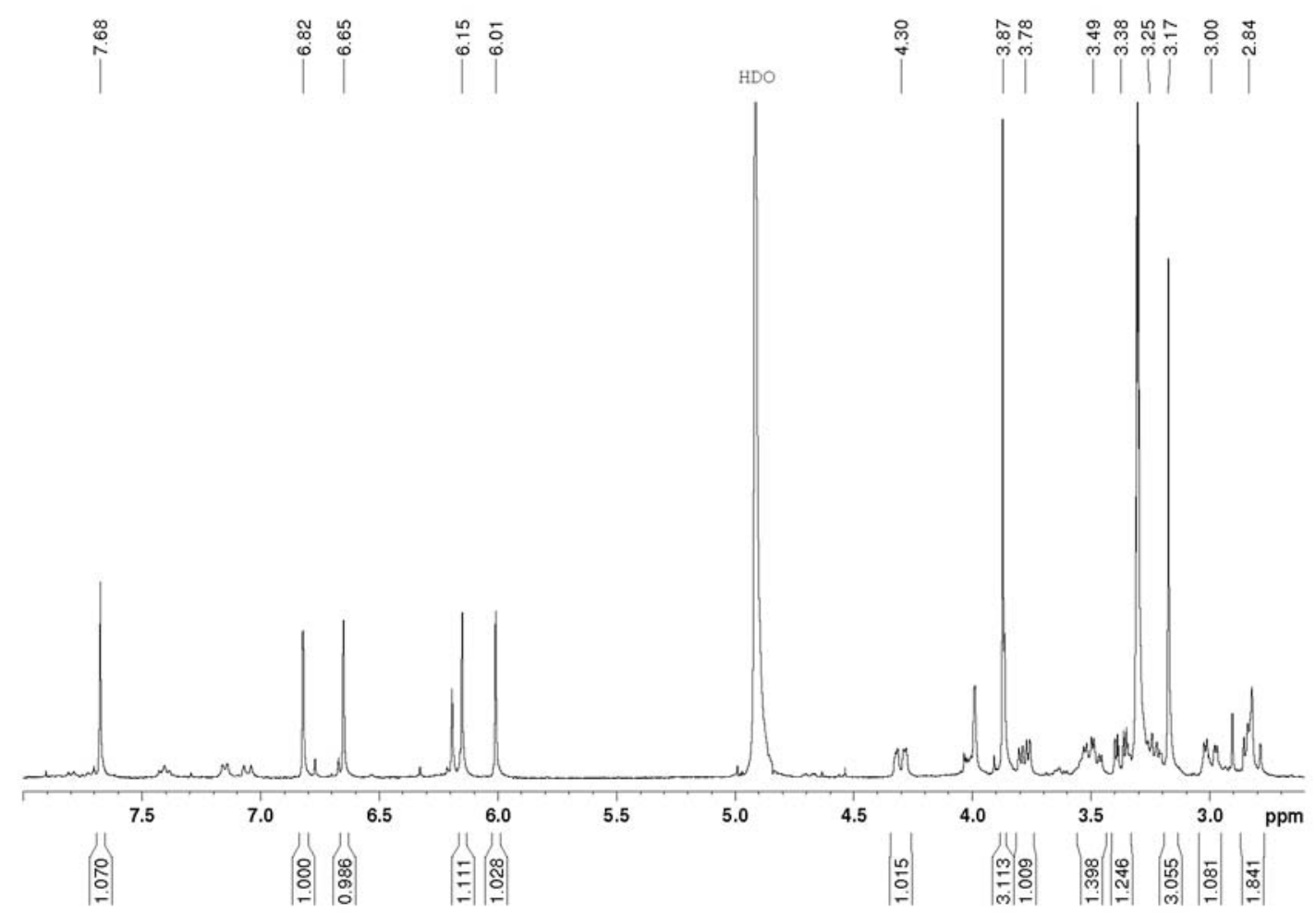

Figure S12. ${ }^{1} \mathrm{H}$ NMR spectrum of cassythicine in MeOD- $d_{4}$ at $400 \mathrm{MHz}$.
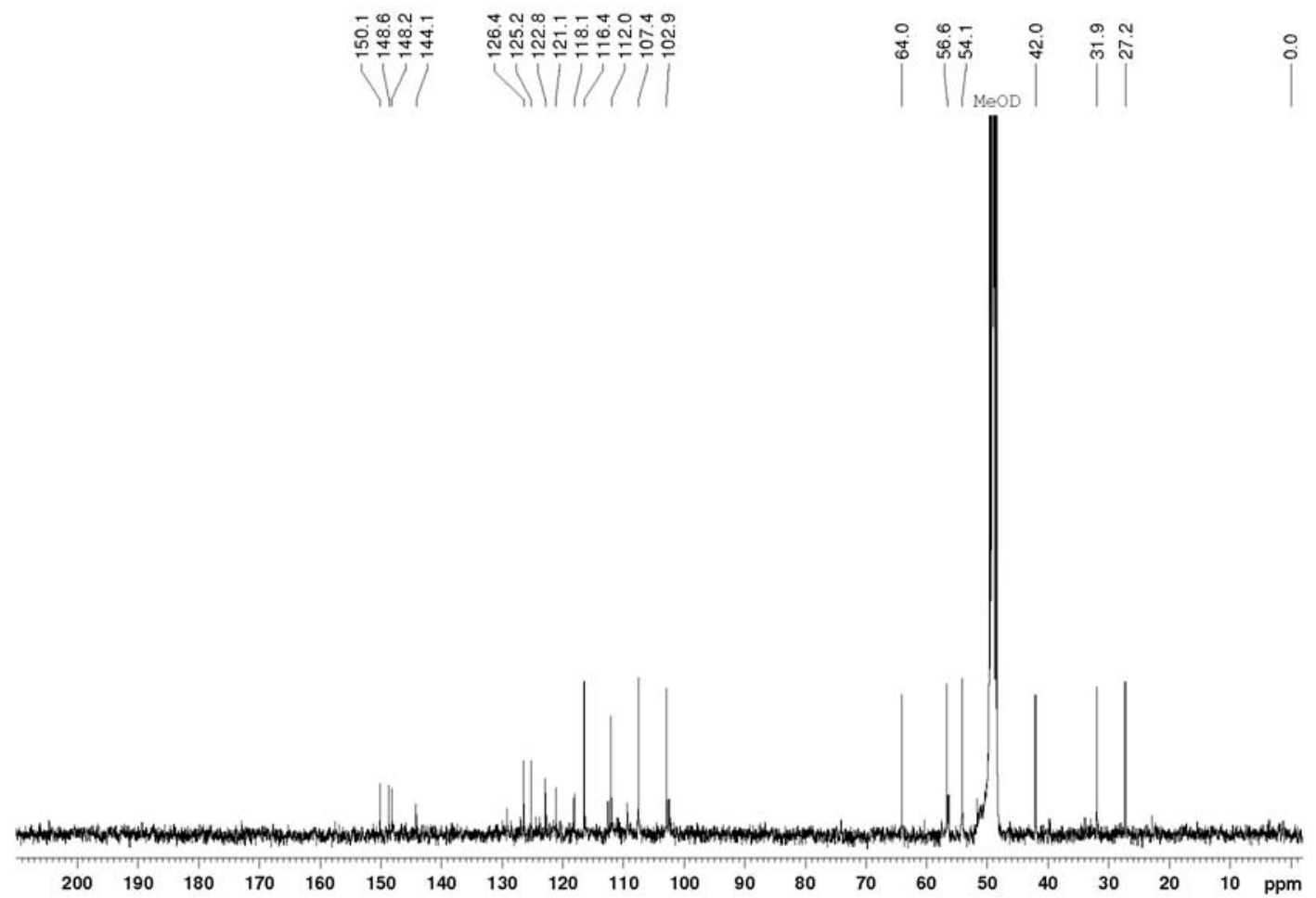

Figure S13. ${ }^{13} \mathrm{C}\left\{{ }^{1} \mathrm{H}\right\}$ NMR spectrum of cassythicine in MeOD- $d_{4}$ at $100 \mathrm{MHz}$. 


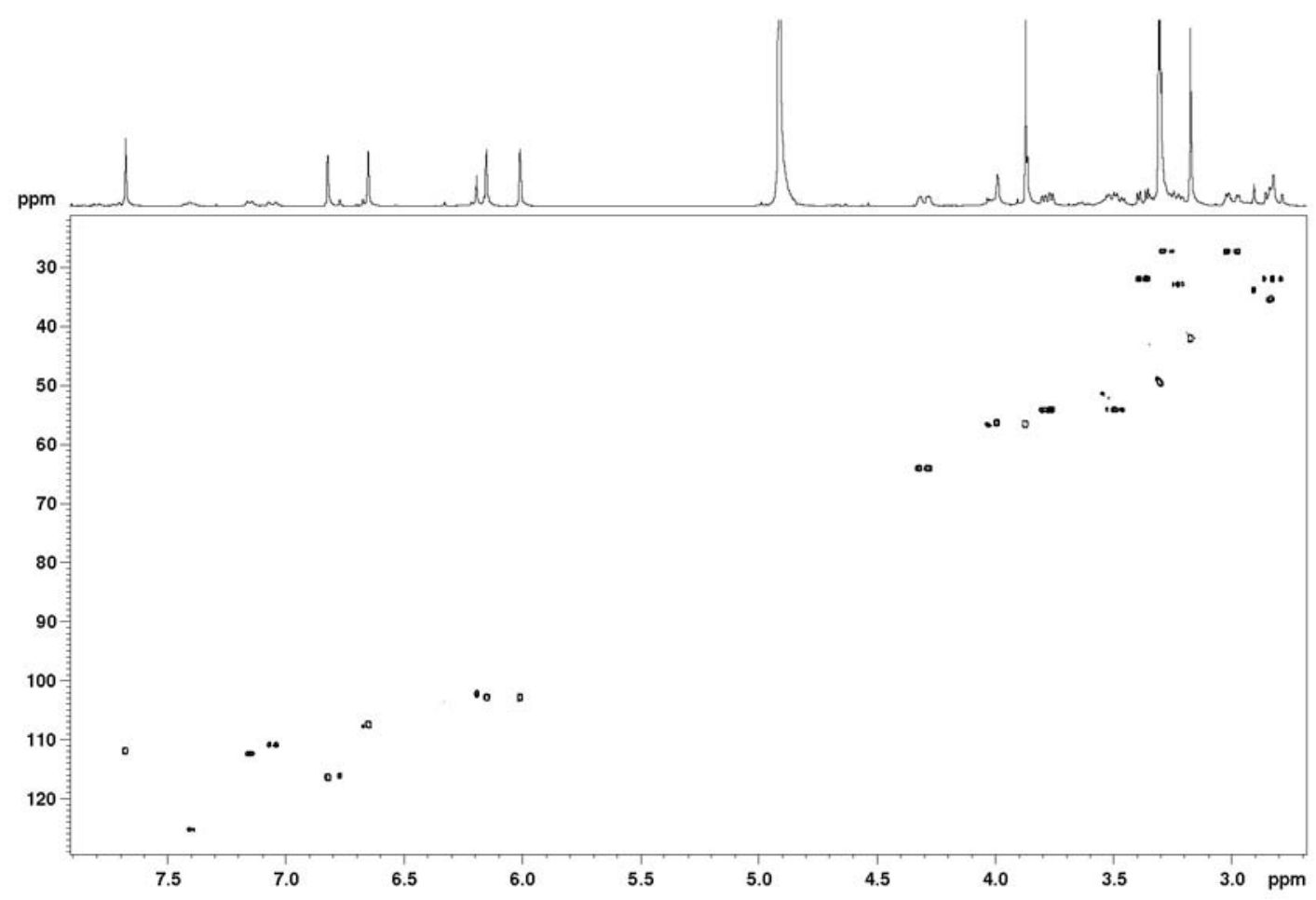

Figure S14. ${ }^{1} \mathrm{H}-{ }^{13} \mathrm{C}$ one-bond correlation map from the HSQC NMR experiment on cassythicine in MeOD- $d_{4}$ at 400 and $100 \mathrm{MHz}$.

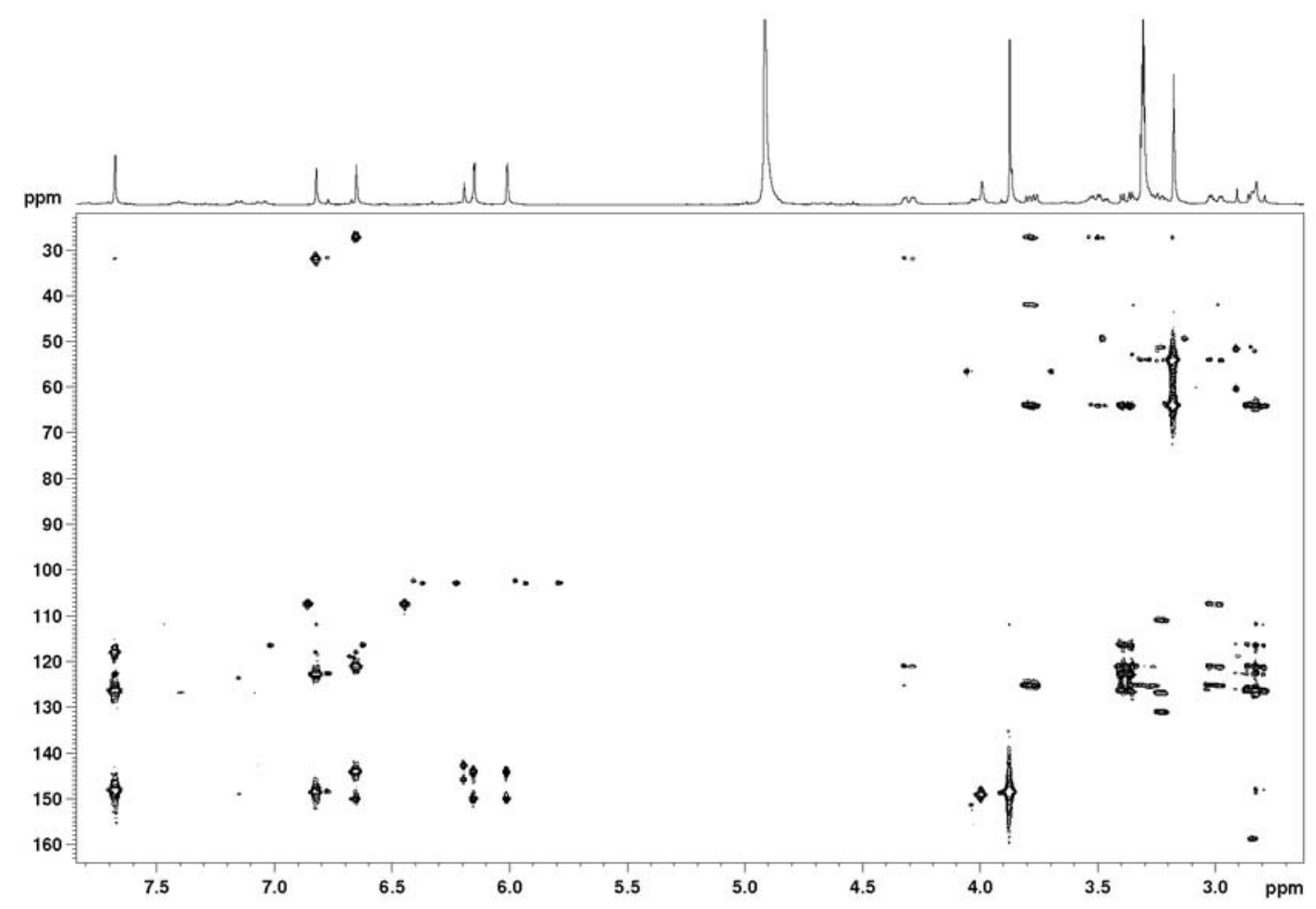

Figure S15. ${ }^{1} \mathrm{H}-{ }^{13} \mathrm{C}$ long-range correlation map from the HMBC NMR experiment on cassythicine in MeOD- $d_{4}$ at 400 and $100 \mathrm{MHz}$. 


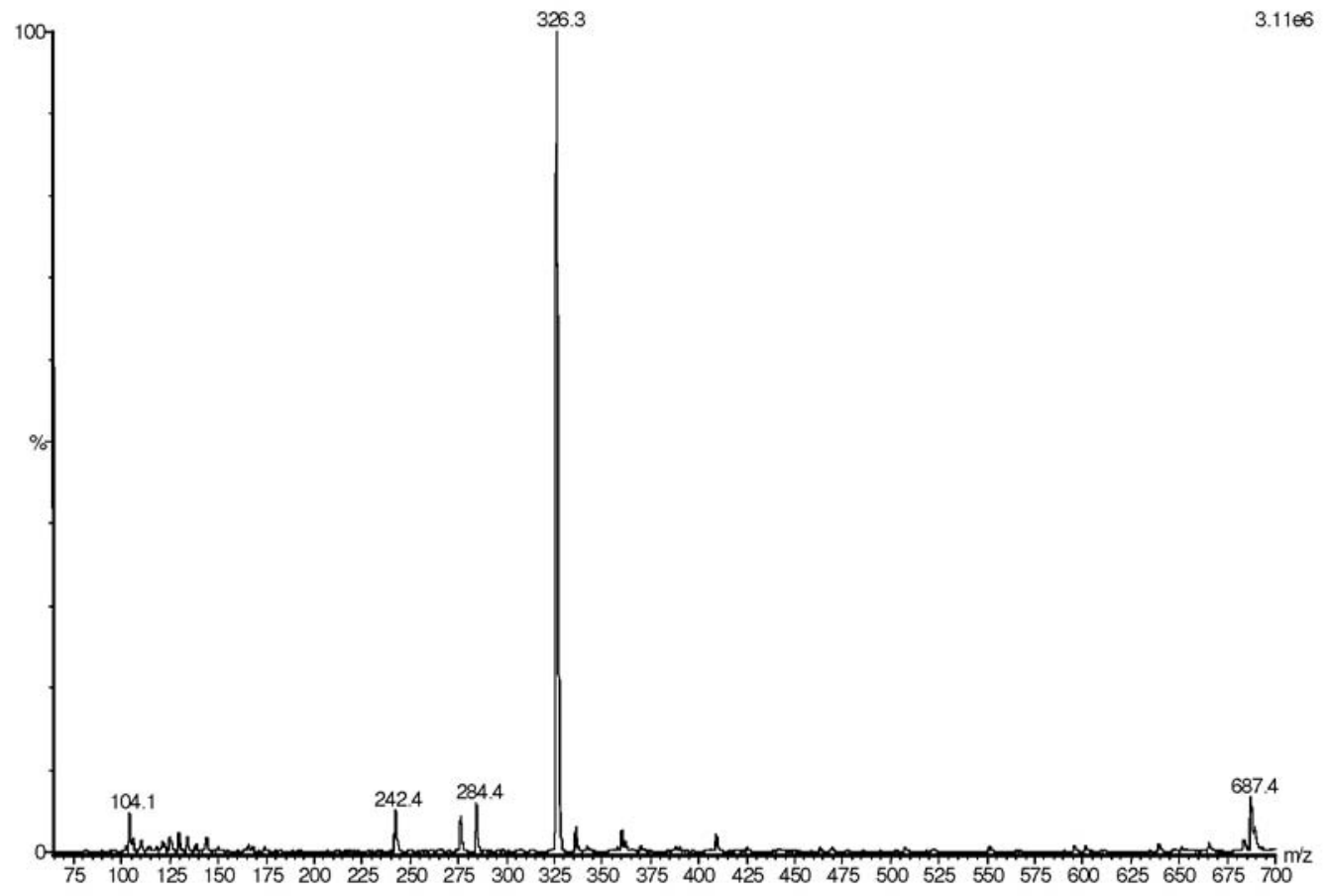

Figure S16. ESI-MS of cassythicine in $\mathrm{MeOH}$, positive mode.

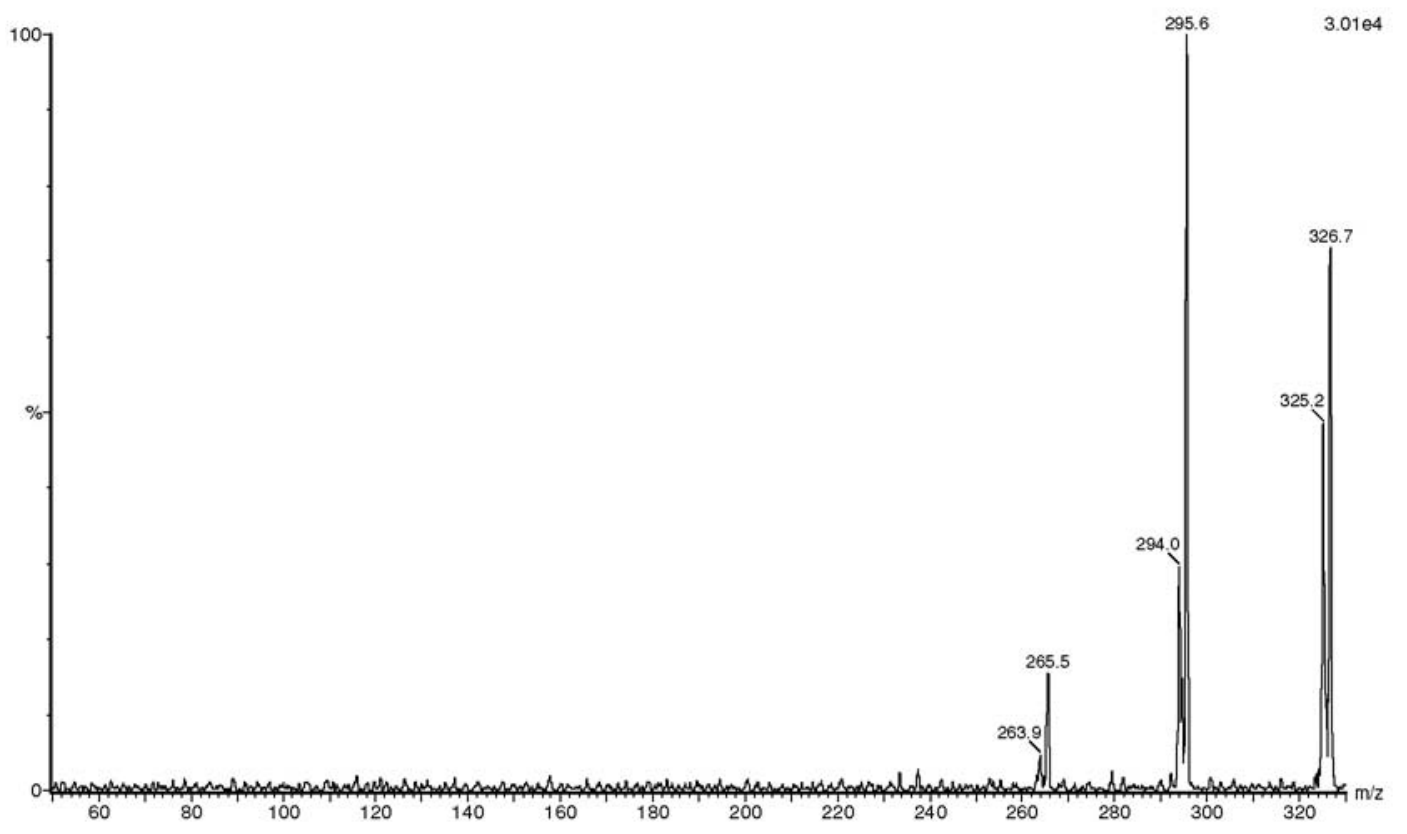

Figure S17. ESI-MS/MS of cassythicine in $\mathrm{MeOH}$, positive mode at $50 \mathrm{eV}$. 


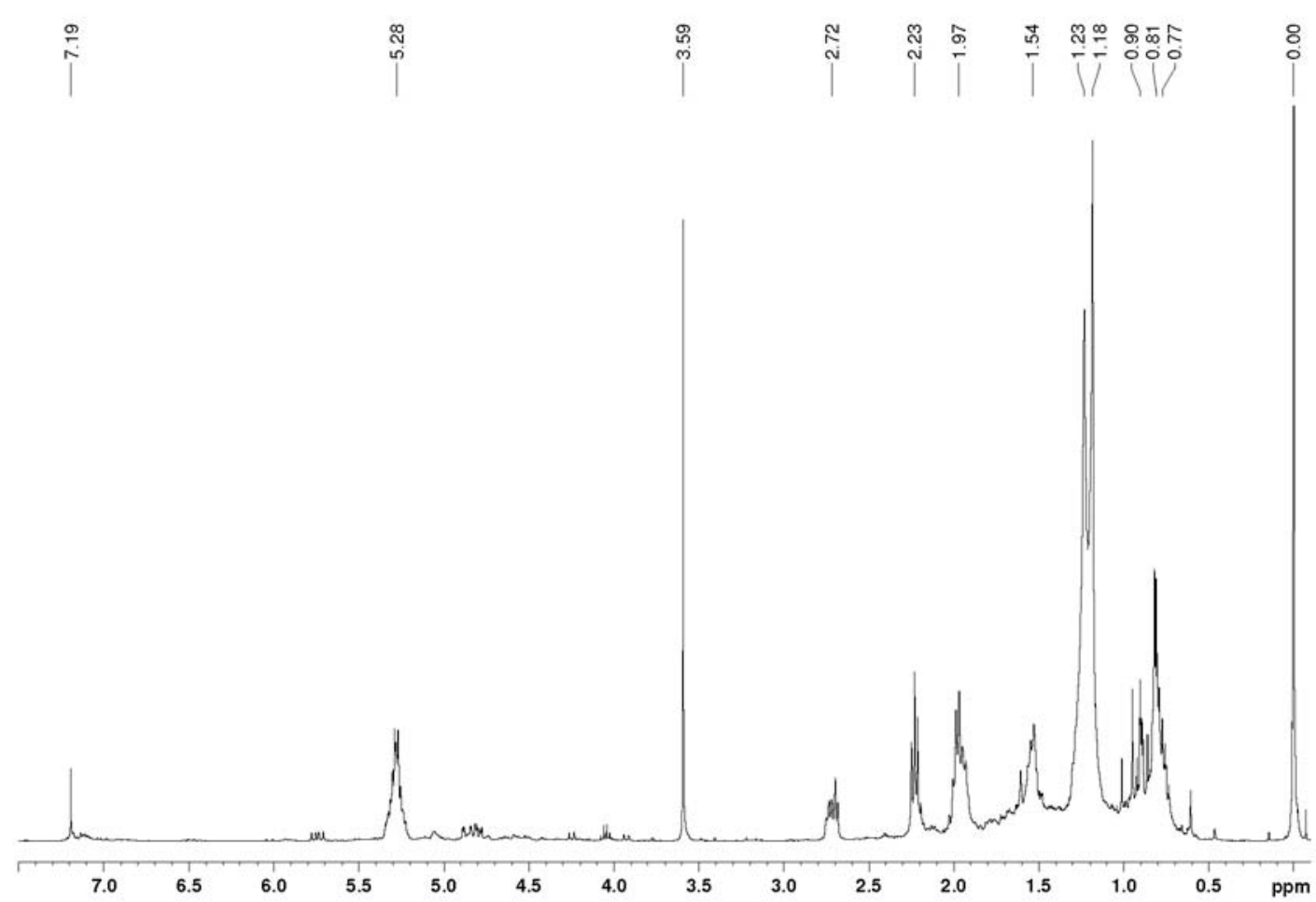

Figure S18. ${ }^{1} \mathrm{H}$ NMR spectrum of the mixture of three methyl esters of the fatty acids, oleic, linoleic, and linolenic in $\mathrm{CDCl}_{3}$ at $400 \mathrm{MHz}^{2}$

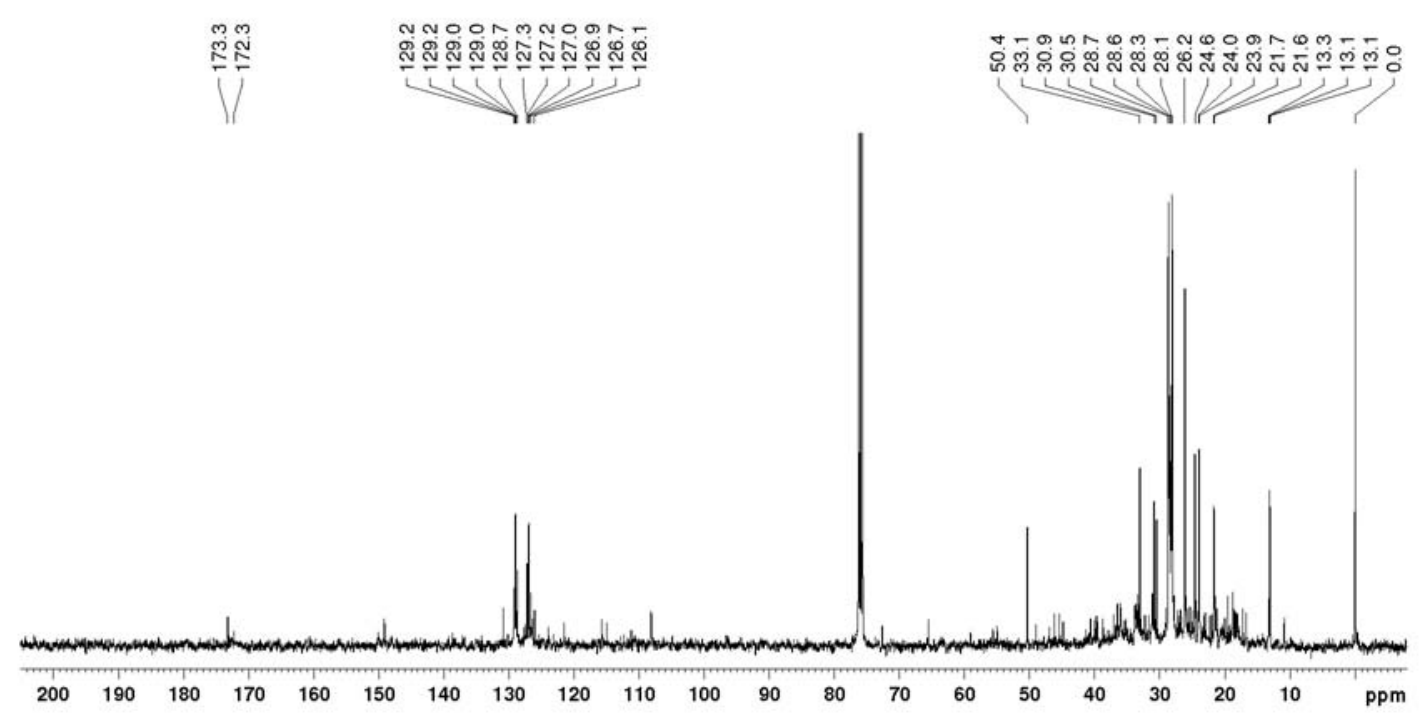

Figure S19. ${ }^{13} \mathrm{C}\left\{{ }^{1} \mathrm{H}\right\}$ spectrum of the mixture of three methyl esters of the fatty acids, oleic, linoleic, and linolenic in $\mathrm{CDCl}_{3}$ at $100 \mathrm{MHz}$. 


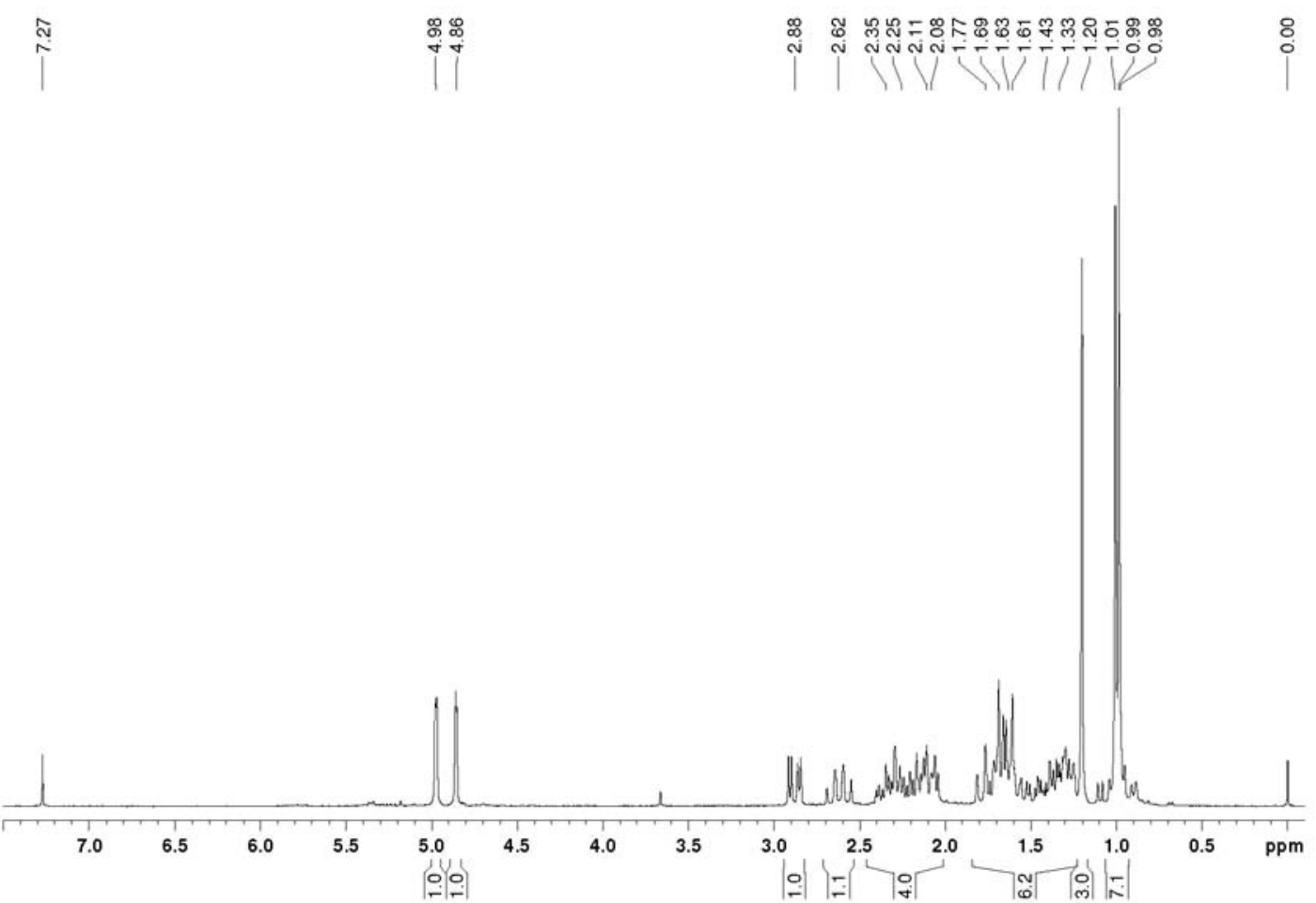

Figure S20. ${ }^{1} \mathrm{H}$ NMR spectrum of caryophyllene oxide in $\mathrm{CDCl}_{3}$ at $200 \mathrm{MHz}$.

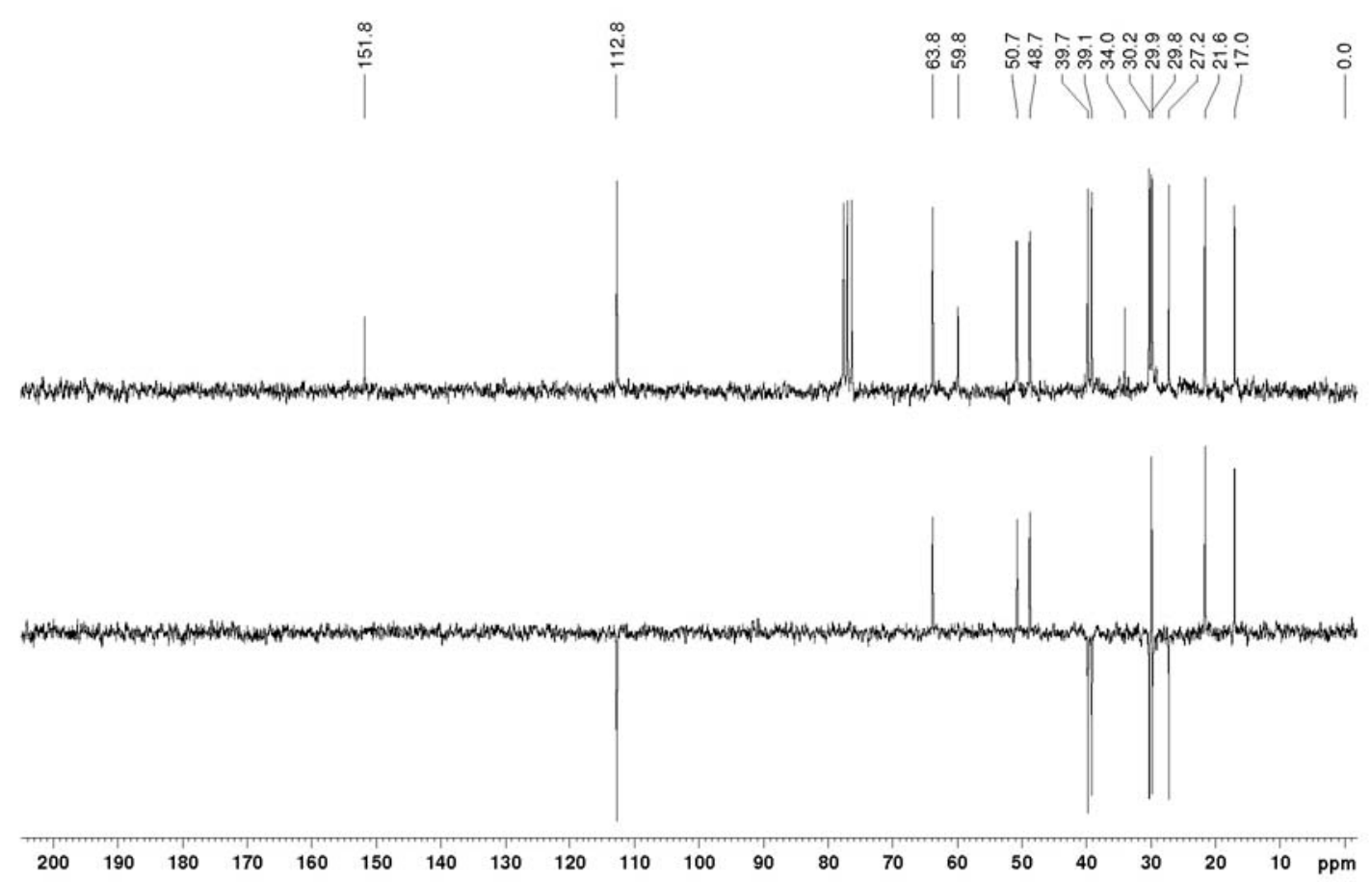

Figure S21. ${ }^{13} \mathrm{C}\left\{{ }^{1} \mathrm{H}\right\}$ and DEPT $135 \mathrm{NMR}$ spectra of caryophyllene oxide in $\mathrm{CDCl}_{3}$ at $50 \mathrm{MHz}$. 
S12

Acanthoic Acid and other Constituents from the Stem of Annona amazonica (Annonaceae)

J. Braz. Chem. Soc.

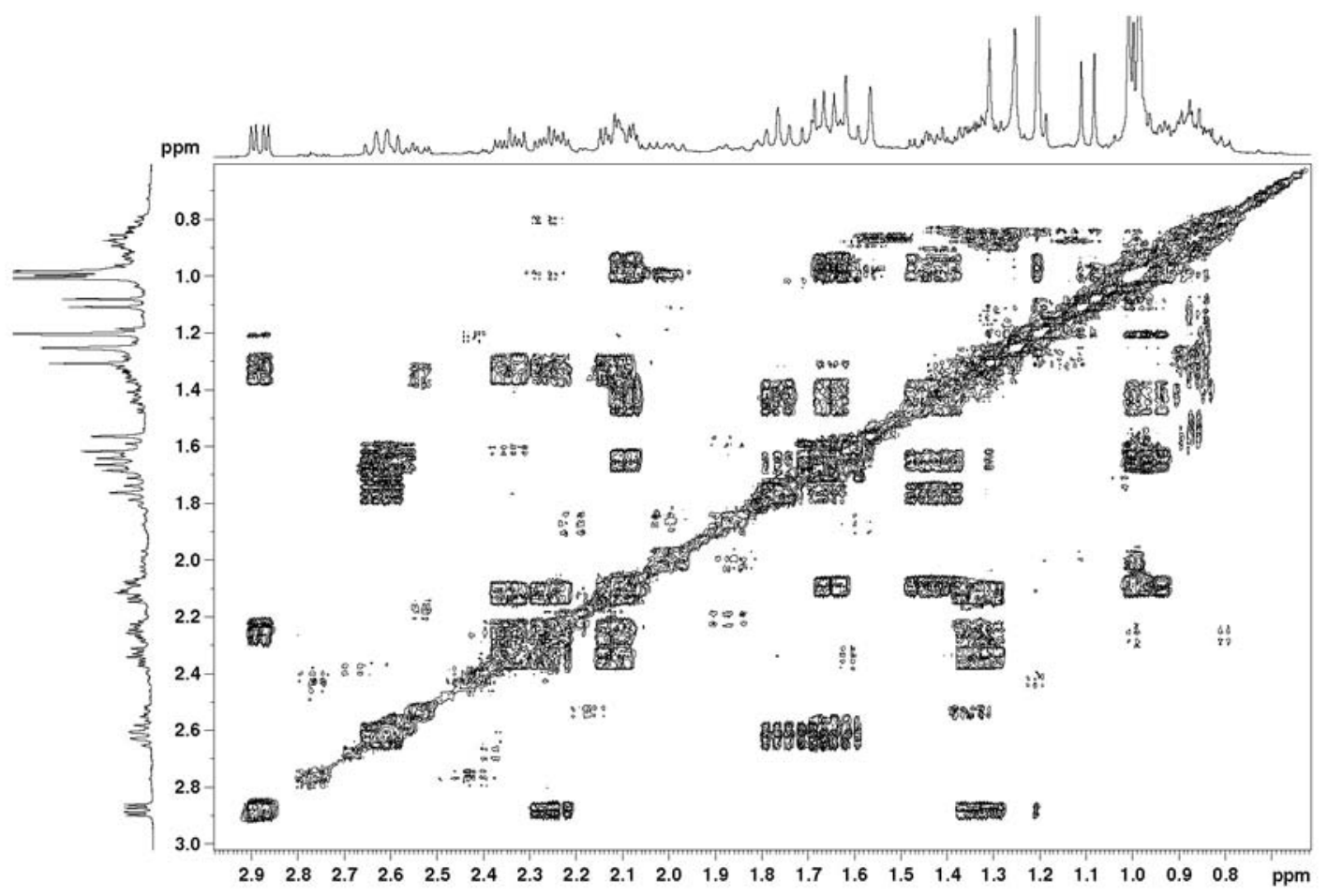

Figure S22. ${ }^{1} \mathrm{H}-{ }^{1} \mathrm{H}$ correlation map from COSY NMR experiment of caryophyllene oxide in $\mathrm{CDCl}_{3}$ at $400 \mathrm{MHz}$

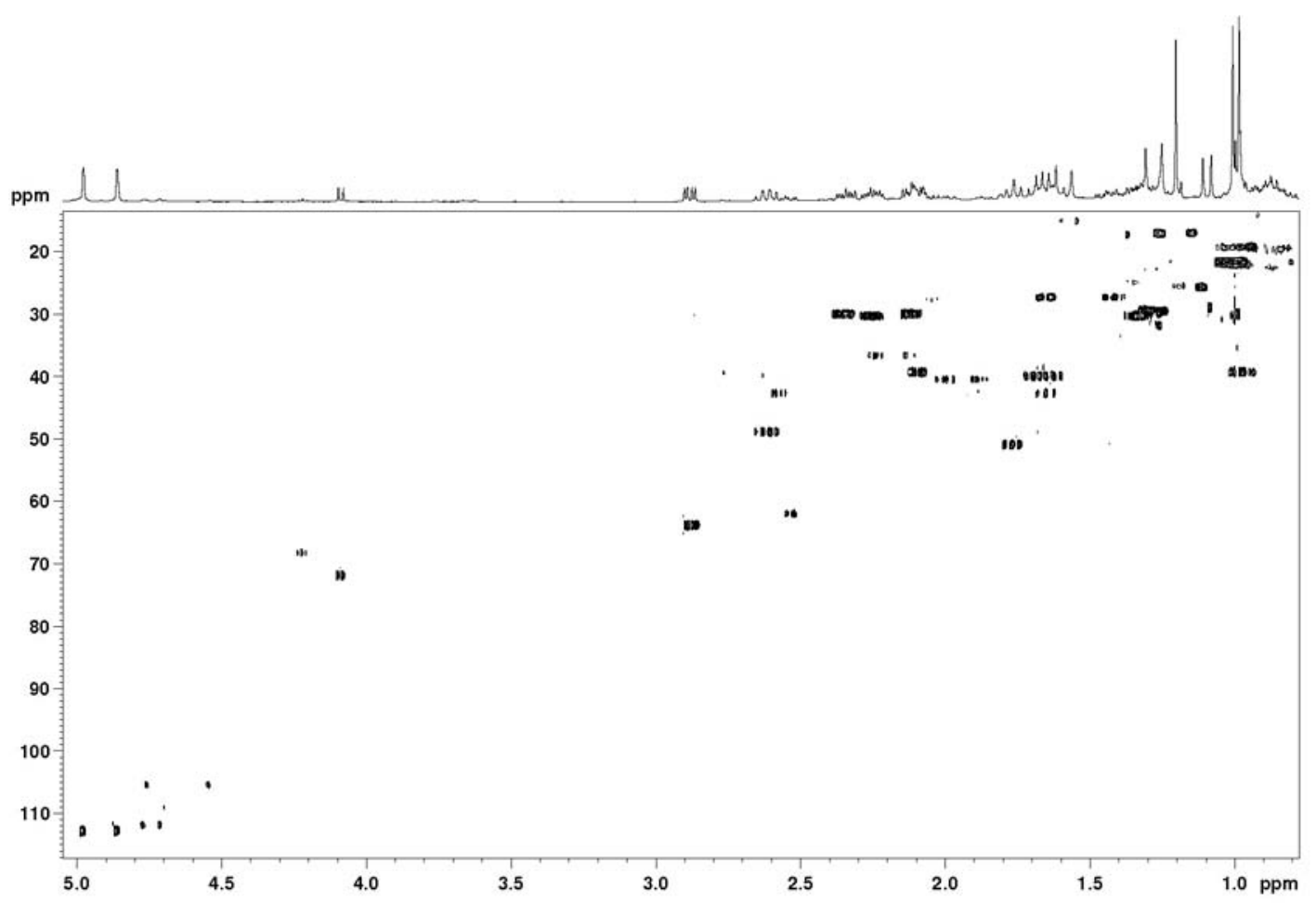

Figure S23. ${ }^{1} \mathrm{H}-{ }^{13} \mathrm{C}$ one-bond correlation map from the HSQC NMR experiment on caryophyllene oxide in $\mathrm{CDCl}_{3}$ at 400 and $100 \mathrm{MHz}$. 


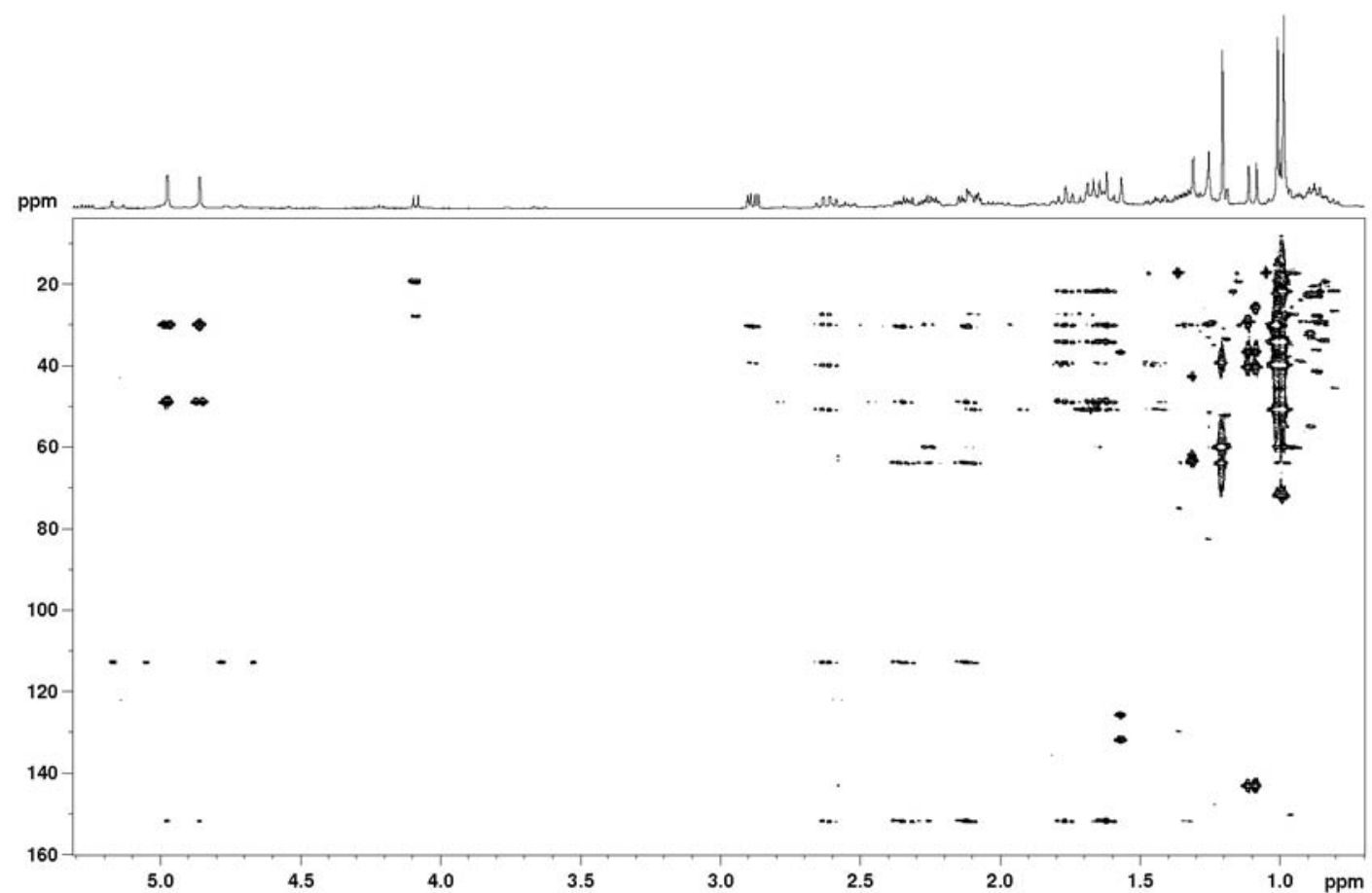

Figure S24. ${ }^{1} \mathrm{H}-{ }^{13} \mathrm{C}$ long-range correlation map from the $\mathrm{HMBC}$ NMR experiment on caryophyllene oxide in $\mathrm{CDCl}_{3}$ at 400 and $100 \mathrm{MHz}$.

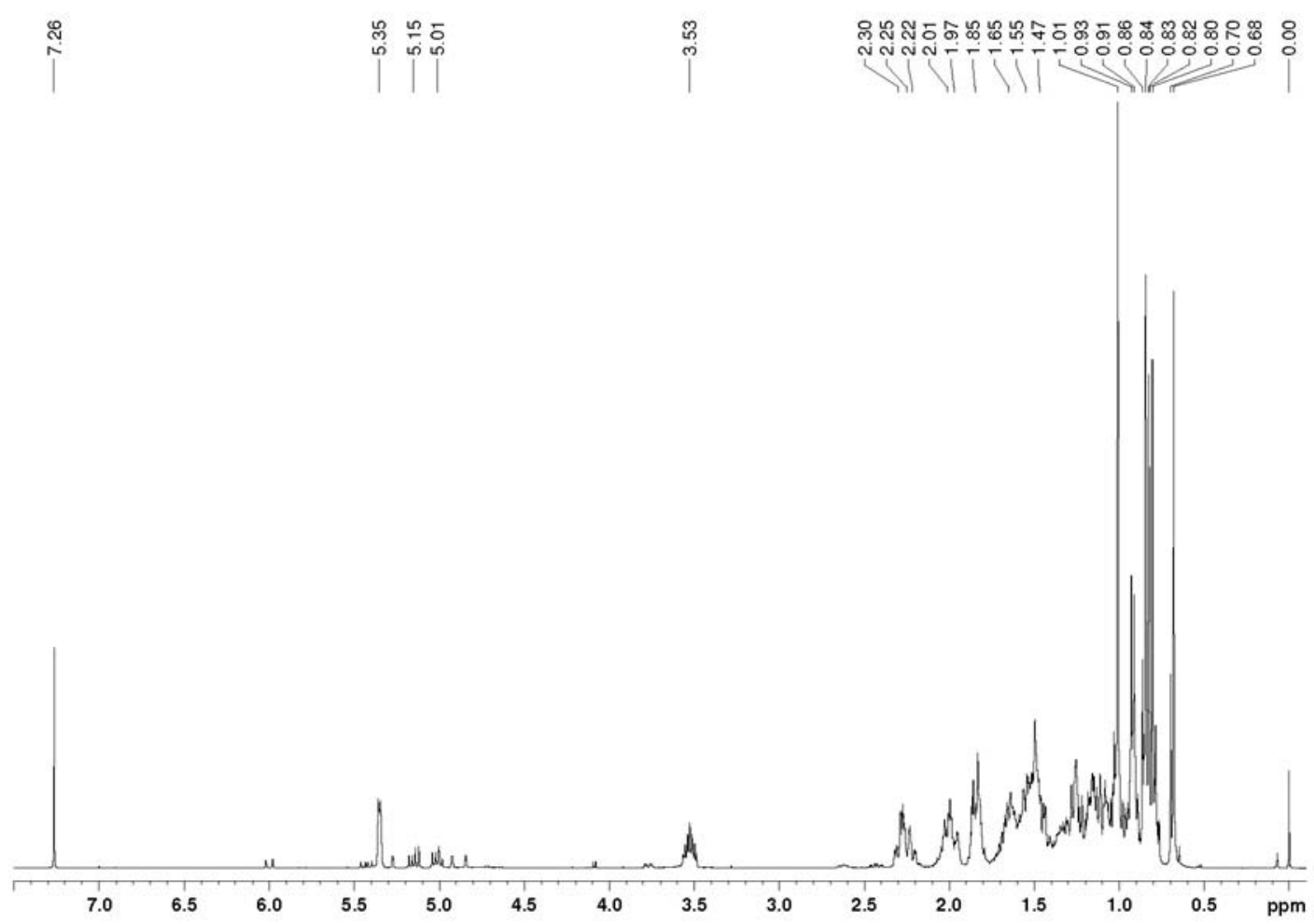

Figure S25. ${ }^{1} \mathrm{H}$ NMR spectrum of $\beta$-sitosterol and stigmasterol mixture in $\mathrm{CDCl}_{3}$ at $400 \mathrm{MHz}$. 


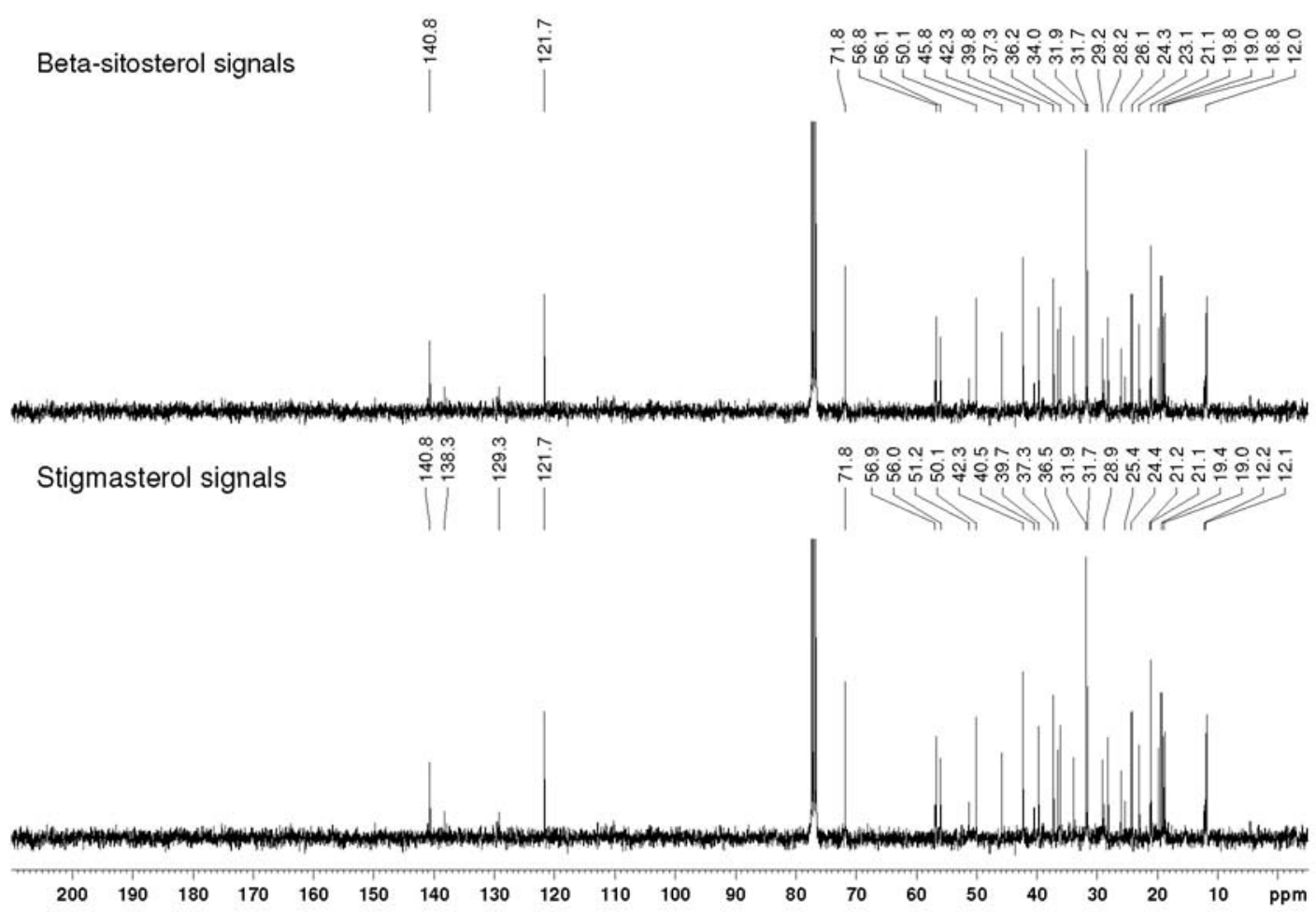

Figure S26. ${ }^{13} \mathrm{C}\left\{{ }^{1} \mathrm{H}\right\}$ NMR spectrum of the $\beta$-sitosterol and stigmasterol mixture in $\mathrm{CDCl}_{3}$ at $100 \mathrm{MHz}$.

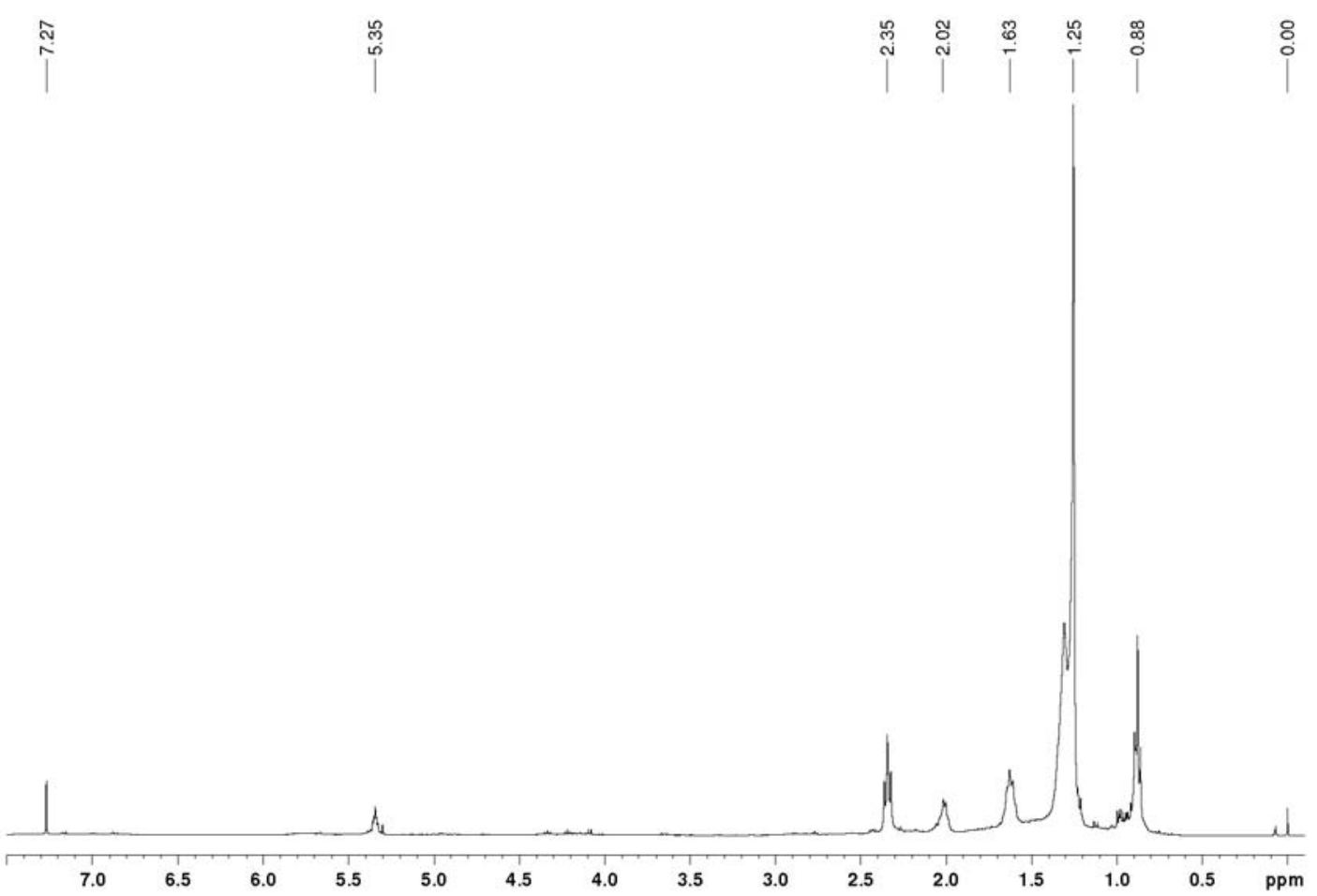

Figure S27. ${ }^{1} \mathrm{H}$ NMR spectrum of oleic acid in $\mathrm{CDCl}_{3}$ at $400 \mathrm{MHz}$. 


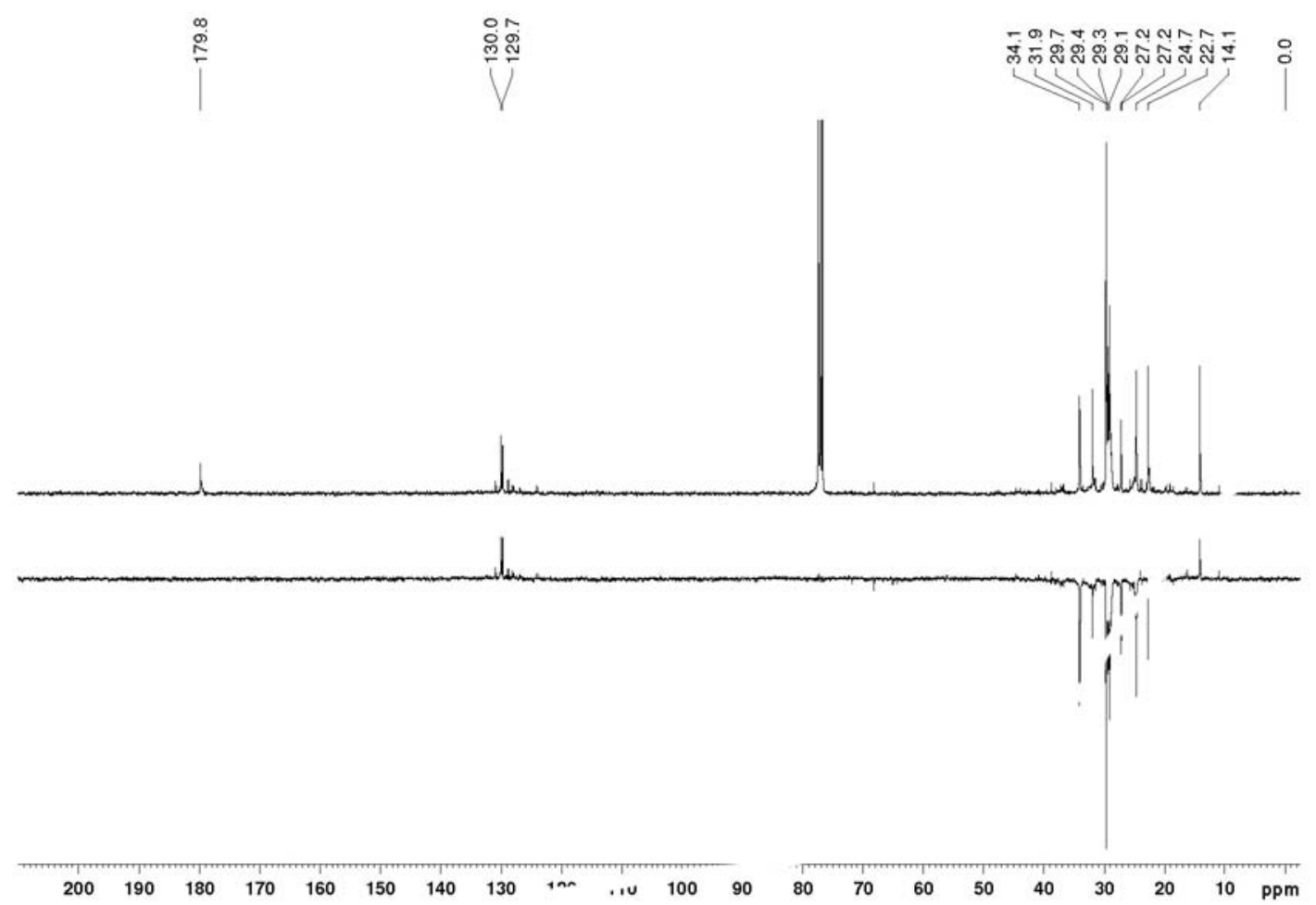

Figure S28. ${ }^{13} \mathrm{C}\left\{{ }^{1} \mathrm{H}\right\}$ and DEPT $135 \mathrm{NMR}$ spectra of oleic acid in $\mathrm{CDCl}_{3}$ at $100 \mathrm{MHz}$. 